\title{
The Dynamics in the Practice of Bukusu Circumcision Ritual Inkenya; Impact of the Inter- Christian Fellowships Evangelical Mission, 1988- 2012
}

\author{
Godfrey Banda Mayende \\ Ph.D. Student, Department of Public Affairs and Environmental Studies of Laikipia University, Kenya
}

\begin{abstract}
This paper is an extract from a Master of Arts Degree Thesis that was presented to Graduate School of Kenyatta University-Kenya in April 2017. The study interrogated the Impact of the Inter-Christian Fellowship Evangelical Mission (IcFEM) on circumcision rituals among the Bukusu community of Kimilili constituency, Bungoma County in the former province of Western Kenya. In this paper however, our contention is to examine one of the objectives addressed in the above mentioned study; the Impact of the Inter-Christian Fellowships Evangelical Mission on circumcision rituals among the Bukusu community of Kimilili Sub-county. Significant to the our findings is the fact that Bukusu circumcision ritual played a wide spectrum of infinite socio-political and economic role in the society and as such, our contention was to demonstrate how status quo was altered upon the inception of new concepts that were not familiar with the traditional setup of the Babukusu. It should be observed that the corroboration of both primary and secondary data was very significant in conducting the field research whose findings were fruitful for the development of this paper. It is indeed true that the target population in the research that preceded this paper was selected using purposive sampling and majority of this population was from the local community within Kimilili Constituency comprising the Bukusu people. Oral Interview (abbreviated as O.I in the entire text) was a key research instrument that was successfully administered to generate substantive findings (Refer to the list of the informants provided in the references section). That aside, significant information was also gathered from the Kenya National Archives (abbreviated as KNA) to enrich the findings of this research.
\end{abstract}

Key words; Traditional circumcision, Inter-Christian Fellowships Evangelical Mission, Bukusu circumcision, hospital circumcision

\section{INTRODUCTION}

\begin{abstract}
A ccording to Makila (1978: 28), the Babukusu are one of the seventeen sub-nations that comprise the Baluhya cluster of the inter-lacustrine Bantu nations of East Africa. Other Luhya sub-groups include; Baragoli, Bamarama, Babedakho, Batiriki, Basamia, Bawanga, Batsotso, Babekisa, Babesukha, Banyore, Batiriki, Batachoni, Bakhayo, Bashisha, Batura and Bakabalas (KNA, DC/NN/3/1: 1902-1916). Today, the Bukusu community largely occupy the present day Bungoma and Trans-Nzoia Counties with a few of them settled in some pockets of Kakamega and Busia Counties.
\end{abstract}

However, some of them have relocated to major towns within the country in search of well-paying jobs while others are out of the country enhancing their studies.

Among other cultures that are well enshrined in the minds of the Babukusu, circumcision is perhaps the most prevalent tradition that has suffered untold attacks and attempts of having it abolished since the inception of colonialism. However, such attempts have not been easily achieved and as correctly reasoned by Doornbos (1975: 103) a centrally placed institution which has lost its essential purpose cannot just fall into oblivion or wither away. Similar to a dilapidated roof, collapse might be obstructed by the remaining walls and beams. One would wonder why this community has exhibited utmost resilience in the practice of their traditional circumcision surgery which has been termed as a barbaric and a primitive culture.

Nevertheless, it should explicitly be told that cultures do change due to many factors including the exposure of a given community to external forces generated by foreign communities and their ideologies. Hoogvelt (1976: 109) argues that no society can fully dominate another without diffusing some of its cultural patterns and social institutions nor can any society successfully diffuse all or most of its cultural patterns and social institutions without some degree of dominance. This argument is also echoed by Havilland (1975: 419) who posit that every culture changes at one time or another for variety of reasons. In support of this notion, Bloom \& Ottong (1987: 236) contends that no culture is static but rather changing. They also observe that there are few cultures where elders do not register disapproval of the departure of the young generation from the traditions of the earlier generations.

Upon the inception of colonialism and Western civilisation in Africa, there emerged a mindset of undoing significant African cultures which were regarded as barbaric and primitive. Indeed, Bell (1986: 72) argues that Africa's sociopolitical and economic structures were profoundly changed during the process of colonial transformation. In Kenya for instance, unsuccessful attempts were instituted to outlaw 
female circumcision. This was the case among the Agikuyu in which the art of clitoridectomy was strongly opposed and attacked by influential European agencies such as missionaries, sentimental pro-African, colonial government, educational and medical authorities (Kenyatta, 1978: 132). This assertion is also articulated by Shell and Hernlund (2000) while interrogating the practice of female genital cutting (FGC) in Africa during the three main historical epochs.

As such therefore, Bukusu circumcision also underwent unexpected transformation in the manner in which it was practiced during the colonial epoch. Kakai (1992) claims that military empowerment to the youth among the Babukusu and the Batachoni during the passing out stage (khukhwiyalula or khukhwalukha) declined during the colonial period because of the adoption of Western clothing that replaced traditional regalia such as skins of specific animals, ekutwa, (traditional hat made from monkey skin) spears and shields. Before then, the passing out stage was climaxed by a mock fight between the initiate and his father.

With the inception of independence, the newly formed government was keen on preserving the cultural heritage of Kenya's diverse cultures including the Bukusu circumcision. However, the medical ground and the hygiene of the Bukusu circumcision was questioned. The entire process of conducting the traditional surgery was criticized for exposing boys to extreme cold condition in the morning and smearing them with mud. This was seen as a health hazard practice because it exposed the candidate to the risks of respiratory diseases such as pneumonia.

Owing to the pressure from non-Bukusu organizations, churches and even the ministry of health, new regulations were introduced to guide Kenyan cultures (Moi, 1983: 204), including the Bukusu circumcision. In 1972 for example, all traditional circumcisers were required to get permits from the ministry of health before they proceeded in the field to conduct the operations (Wasilwa, 2006). Any circumciser who was found conducting his trade without the permit was to be arrested and charged in court. For one to get the permit he was expected to pay Kshs 50 but traditional circumcisers at that time felt that the government was unfairly intruding into their culture (Khalaba, O.I, 2014). Cases of candidates bleeding to death were reported during the bachuma age-set and sometimes, traditional initiators (bakhebi) made wrong cuts on the candidate's organs leading to deformities. This formed the basis upon which the government through the Ministry of Health introduced the idea of acquiring permits by circumcisers.

The emergence of HIV/AIDS in 1984 (Obel 1995: 4 and Wasilwa, 2014: 1) further worsened the woes of the Bukusu circumcision and the government took this chance to make further demands from traditional circumcisers. In addition to the acquisition of annual permits, traditional initiators were also required to attend circumcision seminars that were organized by the same Ministry of health. During such seminars, bakhebi were equipped with knowledge regarding modern methods of hygiene and good conduct during the trade (Khalaba, O.I, 2014). The seminars were conducted annually and successful participants were awarded with certificates to prove their compliance whenever they were asked.

At the same time, circumcisers were expected to be very careful while conducting the surgery to prevent unnecessary cut that may have led to excessive bleeding or sometimes death. For this to be achieved, circumcisers were forced to form an association called Lukembe Sikhebo association of Kenya which was directed by Dr. Isaac Misiko Wasilwa, who was an indigenous research consultant by then (Wasambo, 2013: 106-108). This association was registered in the Ministry of State for National Heritage and culture and it was expected to renew its operation annually. In 2006 association changed its name to Lukembe Bulala Bwe Balusanya, literally translated into English as The Unity of Runners with Circumcision Knives (Wasilwa, 2006).

As expected from any association, Lukembe Bulala Bwe Balusanya laid down rules and regulations that were meant to guide the conduct of circumcisers. Good health devoid of any signs of epilepsy was an important rule that was strictly observed by the circumcisers (Wambani, O.I, 2014). More significantly, exemplary conduct and utmost respect were pertinent aspects of the rules that were expected from the initiators. Additionally, initiators were required to identify themselves while on duty through unique regalia that comprised uniforms and identification badges.

Beside the above rules, circumcisers were expected tohave many circumcision knives (ching'embe) and the rationale for this rule was to end the idea of using one knife to conduct the surgery to as many boys as possible (Wasilwa, 2006). Prior to the arrival of HIV/AIDS in Kenya, one knife was used to circumcise up to four candidates (Wagner, 1949: 350) and this practice was prohibited by the association. More fundamentally any circumciser who had at one time circumcised a corpse was not permitted to conduct the operation (Wasilwa, 2006). The mention of the circumcision of corpse before burial among the Babukusu is however, contestable. It sounds ridiculous, unethical, unreasonable and awkward for them to circumcise their corpses. Perhaps, the reason behind this cultural routine was due to the fact that they believed in life after death. Arguably, it was mandatory therefore, for Bukusu men who died before undergoing the surgery to be circumcised. And that is why traditional surgeons who may have circumcised corpses were outlawed from conducting surgeries to boys.

Stability while running to conduct the surgery was a vital rule that should not be gainsaid. Falling down was a bad omen hence any initiator who had fallen down at one time was not supposed to conduct the traditional surgery. At the same time, they were also forbidden from using their tools of trade to fight. In fact it was an abomination for the initiator to even 
threaten anybody using that knife (Makila, 1982: 130). More fundamentally, all circumcisers were expected to be married and had sired boys as their first born children. They were also expected to take an oath of loyalty traditionally called lubito.

That aside, circumcisers were not expected to argue on who among them would circumcise the candidate. Such unnecessary competition and arguments were discouraged because they spelt doom and misfortunes to the boy. Hence, the choice of the circumciser was a sole responsibility of the boy's father and other patriarchs that were related to the candidate. Furthermore, it was wrong for one circumciser to conduct khubita (moral counseling) to boys who were circumcised in hospital. Additionally, the Khubita ritual was reserved to circumcisers whose sons had already undergone the traditional surgery. All in all, circumcisers were prohibited from being jealous to one another when the candidate was approaching home to be cut (Wasilwa, 2006).

It is at this juncture that Inter - Christian Fellowship Evangelical Mission (IcFEM) opted to join the Bukusu circumcision fiasco that was already under immense pressure to abandon its resilience in practicing the ritual in its traditional setup. Being a local based organization situated in Kimilili constituency, IcFEM was founded on the Biblical concepts and doctrines which made it a "Godly" organization. It was established in 1988 by Mr. Solomon Nabie together with Samson Mutuba, Tatwa Mwachi, Esther Ayuma, Elizabeth Nasirutia, Ruth Eshimuli Nabie, Francis Bushebi and Elijah Malenje (Biboko, O.I, 2015). With time, IcFEM attracted other local people to join and by December 2012, the Mission had involved itself in projects which transformed the living standards of the local people. However, the mission's entry into the provision of hospital circumcision to the local people was received with mixed reactions. Nevertheless, it left a remarkable impact on the practice of circumcision to the local people.

\section{OBJECTIVE OF THE STUDY}

The main objective of this study was to assess the impact of IcFEM on circumcision rituals among the Bukusu community but for this to be effectively realized, it was imperative to also establish the significant reasons why the Bukusu community has continued to practice the traditional ritual amidst opposition from so many people and organizations. Other important objectives in this study included the following: examining the cultural anthropology of Bukusu circumcision, the origin and the growth of IcFEM in Kimilili constituency, IcFEM and male circumcision projects in Kimilili and the socio-political and economic impact of IcFEM on Bukusu circumcision ritual in Kimilili constituency.

\section{STUDY LOCALE}

The study was undertaken in Kimilili constituency which is located on the North Eastern part of the larger Bungoma County along the slopes of Mt. Elgon, approximately 450 kilometers from Nairobi, Kenya's capital. It is bordered by
Tongareni Division in the East, Webuye town in the South East, Chwele and Sirisia Divisions in the West and Mt. Elgon District in the North. The constituency has a total of four locations; Maeni, Kimilili, Kibingei and Kamukuywa (See the maps below).

The map of Kenya showing the location of Kimilili constituency

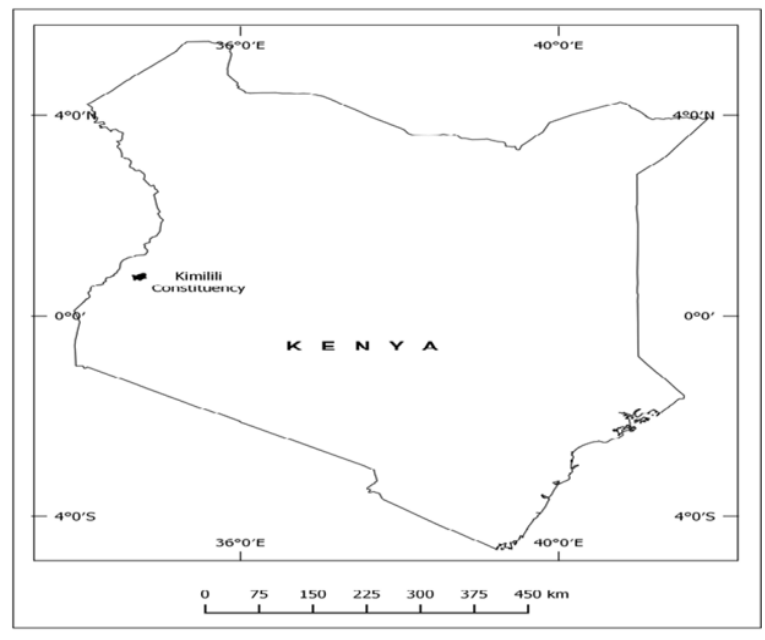

Figure 1: The map of Kenya showing the location of Kimiliti constituency.
Source: Kenyatta University, Geography department.

\section{ETHICAL CONSIDERATION}

During field work, ethical considerations and requirements were fully observed. Foremost, a research permit was issued by the National Commission for Science, Technology and Innovation (NACOSTI) upon the approval of the research proposal by the Graduate School of Kenyatta University. The researcher also obtained authorization letters to conduct the study from the Ministry of Education Science and Technology and the Ministry of Interior and Coordination of National Government in Kimilili Bungoma sub-county. That aside, the researcher also obtained a written permission from Mr. Solomon Nabie (IcFEM Director) to conduct the research within his institution.

The map of Bungoma County showing the location of the study area

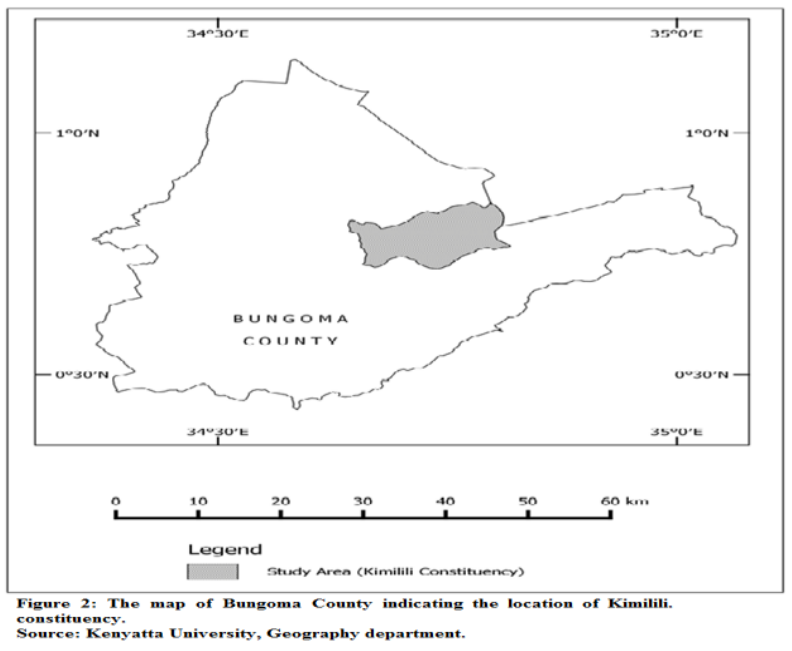




\section{RESEARCH METHODOLOGY}

This study adopted both purposive and snowball sampling techniques. Under purposive sampling, subjects are handpicked because they are informative and also possess the required characteristics. Snowball sampling on the other hand is a technique where the few identified subjects under purposive sampling propose other informants that have the required characteristics.

The study also incorporated both primary and secondary data. Primary data was collected from the field through extensive interviews. It was also sourced from the Kenya National Archives which was very relevant in giving government and annual reports during the colonial and post-independent periods. Besides using primary data, secondary data was also relevant and most of this data was collected through reading of text books, journals, dissertations, magazines and on-line literature. This source of data collection was however subjected to textual criticism to test the relevance and the accuracy of the collected information.

The main research instrument that was used in this study was the application of the interview schedules. The researcher interviewed various respondents and informants who were familiar with the Bukusu circumcision and IcFEM. Boys who had been circumcised through traditional method as well as IcFEM medical team were interviewed. The researcher also interviewed traditional circumcisers, Bukusu village elders, married women, IcFEM administrators and local administration authority. However, questionnaires became relevant when some informants declined to be interviewed due to their own personal reasons.

\section{DISCUSSION AND FINDINGS}

\section{Cultural Anthropology of Bukusu circumcision ritual}

Bukusu circumcision is a ceremonial cultural ritual which follows systematic steps that contain significant symbolic actions both to the initiate and to the entire community. This is according to Wanyama and Egesa (2014: 6) whose sentiments are also echoed by Khamalwa (2004: 74) who postulate significant stages of circumcision rituals among the Bamasaba of Uganda. Note that Bamasaba of Eastern Uganda are close brothers to Babukusu. Infact Mubukusu (the eponymous founder of the Babukusu) and Masaba (the eponymous founder of Bamasaba) are historically said to be sons of Mundu, the only known ancestor of these two communities. That is why Makila (1978: 46) argues that if the Babukusu are Baluyha by virtue of their geographical circumstance, they are first and foremost members of a duplex community incorporating the Bamasaba of Uganda by the virtue of historical circumstance. Culturally, they intermarry, speak almost similar language and more fundamentally, they practice the same circumcision rites with the exception of few differences in terms of the process of performing the surgery.

The ritual takes place after every two years in the month of August and (Khamalwa, 2004: 74) posits that the rite it is carried out during even years for example 2014, 2016, 2018, 2020 etc. The Babukusu associates even numbers with good luck (Wanyama, 2005) unlike odd years (sikumenya) which are associated with bad luck and misfortunes that may befall the initiates and the entire community. This was the case between 1935 and 1941 where most initiates who underwent the surgery in 1935, 1937, 1939 and 1941 died mysteriously while in the seclusion period (Walekhwa (O.I, 2014). It is these alarming occurrences that informed the then Bukusu leadership to outlaw conducting the surgery during odd years.

As a cultural rite, Bukusu circumcision has elaborate phases that are purposeful and meaningful. Wanyama and Egesa (2014: 6) contends that Bukusu circumcision has three main phases namely preparation, actual circumcision and postcircumcision rituals. This argument is inconsonant with the WHO (2009: 3) which outlines three phases of conducting the surgery similar to what Wanyama and Egesa outlines. Seemingly, Makila (1982: 124-136) suggests four stages in Bukusu circumcision which include preparations, actual operation, life of the initiates and the feast of coming out.

Significantly therefore, preparations for the surgery was a key stage which was keenly taken into consideration by important stakeholders in the boy's circumcision party (Wagner 1949: 337 and Mugambi \& Kirima, 1976: 40-43). Makila (1982: 124) notes that the candidate was responsible for buying handbells (chinyimba) from blacksmiths in readiness for the anticipated circumcision ceremony (see the photo below of the chinyinmba).

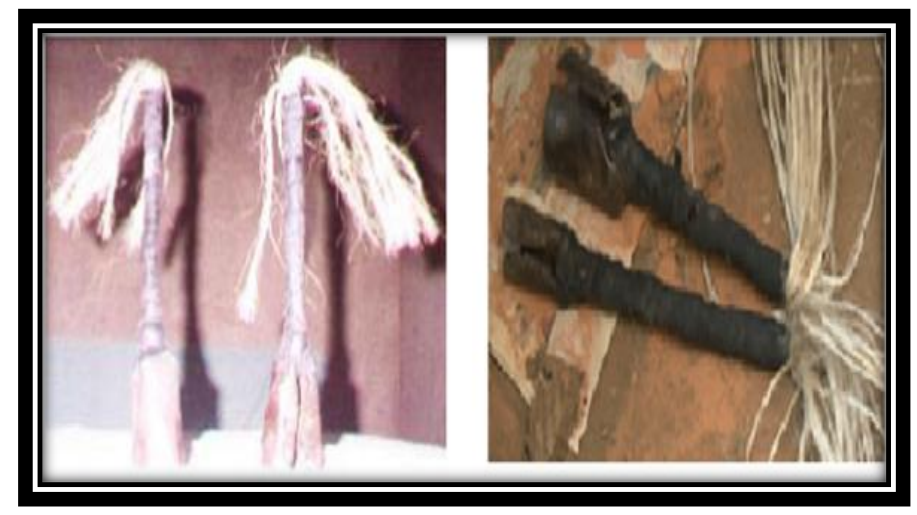

Upon the preparation of chinyimba and the metallic wrings worn around the wrists (birere), the candidate commenced his formal practice of playing chinyimba. This practice is similar to what Khamalwa (2004: 74) calls the Isonja or group dance.

Besides this formal practice by the boy, the father was expected to raise or buy a bullock to be slaughtered in his son's circumcision ceremony while the mother was supposed to put in place adequate requirements for the provision of enough food and traditional liquor (busaa) for the many anticipated guests in the ceremony. The maternal uncle (khocha) was also notified in advance about his nephew's intention of undergoing the surgery so that he could also 
prepare a bull to be offered to the candidate on the day before the actual operation.

As the month of august approached, the circumcision date was fixed and this was a clear sanction for the boy to start moving around the village inviting relatives, friends and neighbours to join him in celebrating his big day (Makila, 1982: 125). During this formal visits and invitations, the candidate was expected to play chinyimba and his companions engaged in singing circumcision chants throughout the visits. Traditionally, these visits and invitations were called khulanga(see the photo below of khulanga process).

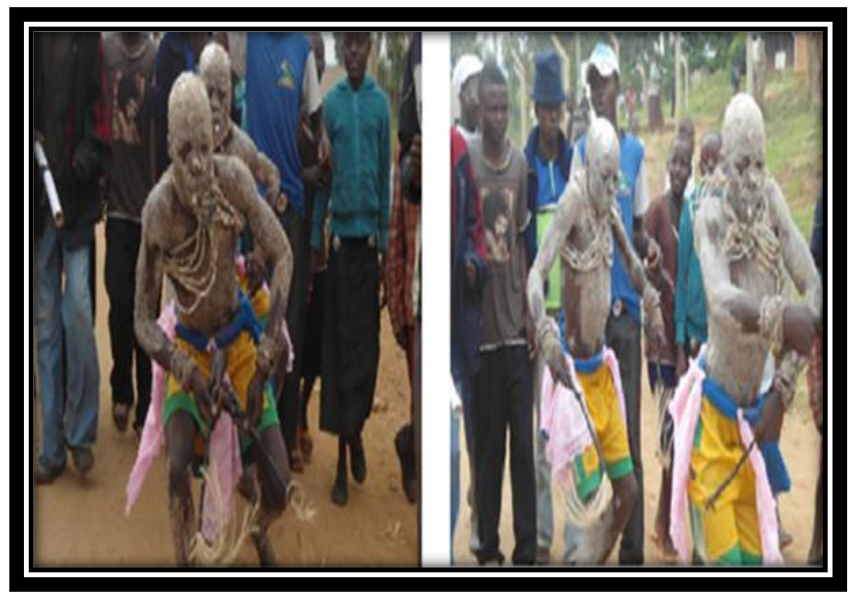

Three to four days before the material day, the candidate was involved in the beer making process that was traditionally called khuchukhila (Wagner, 1949: 342). Fermented maize flour was normally fried to produce brown substances or roasted dough traditionally called chimuma or kamakhalange. A pot containing some of these chimuma was placed outside the boy's father's house and he was instructed to fetch water from the nearby river which he poured into the chimuma placed in the pot to initiate the process of beer brewing (Khamalwa, 2004: 78). Upon accomplishing this task, elders for the first time sang the famous sioyaye chant while teasing the boy for taking up a dangerous turn in his life (Makila, 1982: 126). The candidate was then escorted to invite his paternal aunt (senge)who also played a key role in the boy's circumcision (see the photo below of the beer brewing process).
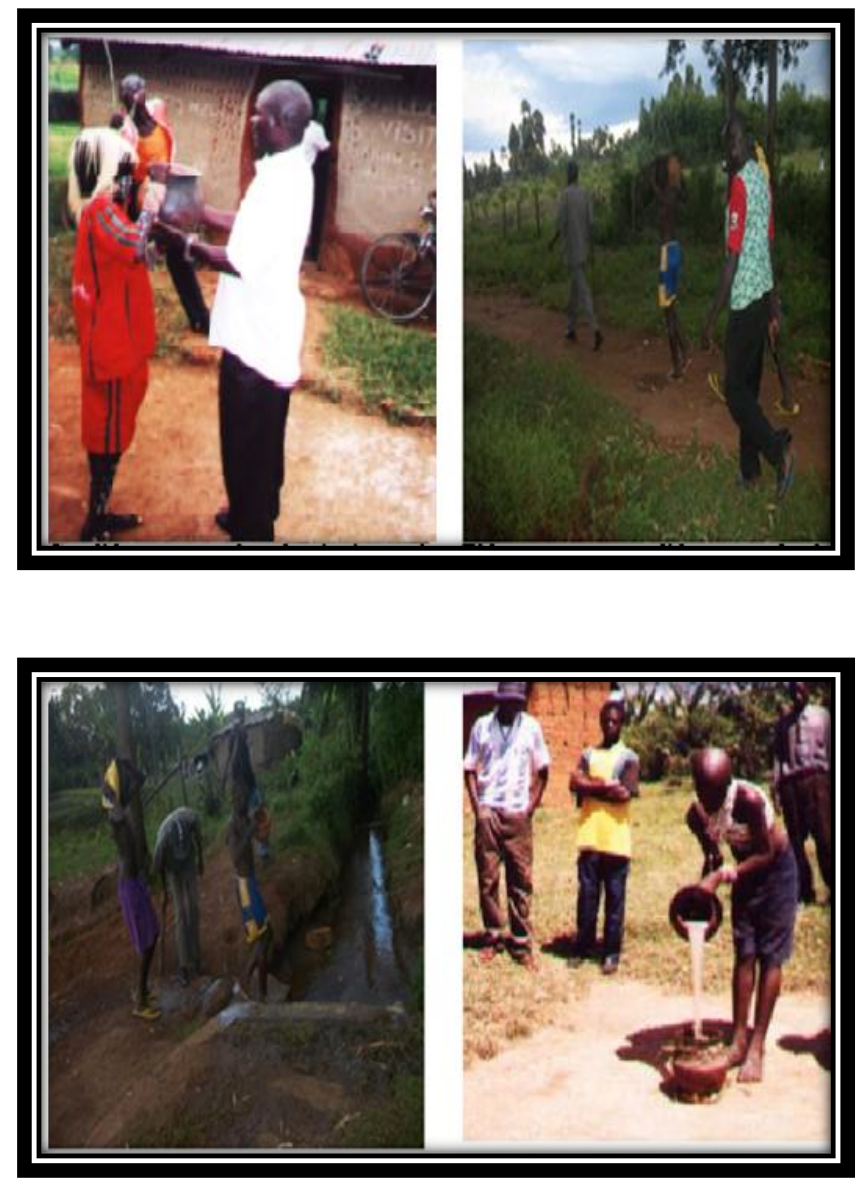

The visit to the maiden uncle (khucha ebukhocha) was another vital phase in Bukusu circumcision ritual which was accorded due respect it deserved and it also marked the climax of all visitations made earlier. This visit ideally allowed the boy to formerly seek his maternal clan's permission to undergo the surgery as well as receiving their final blessings. As a sign of accepting the request, the maternal uncles gave out a bull to the boy as a way of reciprocating the benefits accrued from the dowry that proceeded after the marriage of the candidate's mother. Khamalwa (2004: 86) observes that it was a mandatory cultural duty for the maiden uncle to accomplish this task. Traditionally, this bull was called likhoni and sometimes, it was slaughtered and the bullock's breast meat (luliki) was hung around the boy's neck to take home. Again, the sioyaye chant was sang and this signaled the journey back home for the final phase before the surgery was done the following day in the morning.

A day before the real surgery, a bull was slaughtered at the boy's home and the entrails were put next to a shrine which was traditionally called namwima(see the photo below of the namwima). 


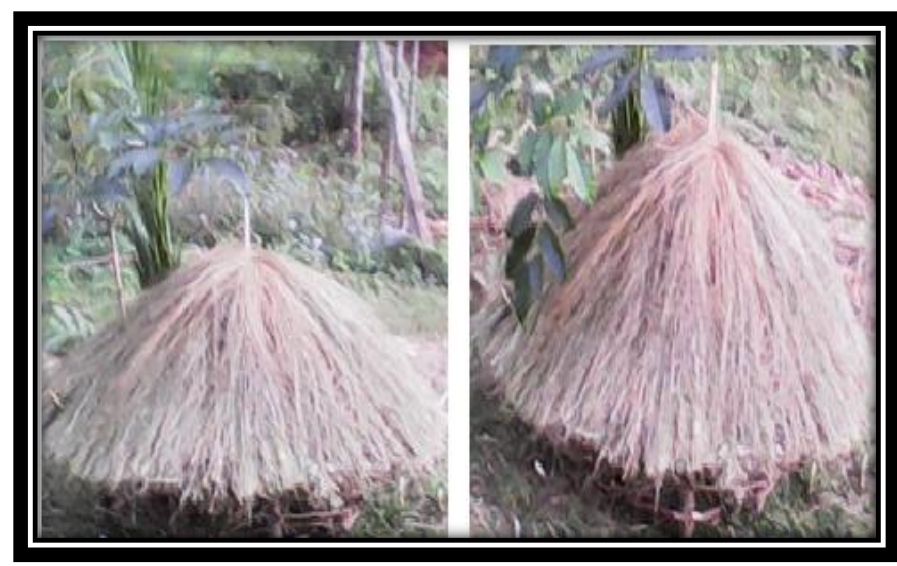

Part of the bull's rumen meat was hung around the boy's neck after which he intermittedly jungled his chinyimba amid songs, trot and dance. Traditionally, the night dancing, singing and feasting was called khuminya. By this time, the invited relatives and guests including the father's age-sets (bakoki) had already assembled at the boy's home. Wanyama and Egesa (2015: 11) argues that such people were expected to spend the whole night there singing, dancing, feasting, chatting the finalities to the event and cohesively waiting to witness the circumcision of the boy the following day in the morning. The candidate by this time was only wearing the pants and he had to endure unbearable cold throughout the night (see the photos below of the night singing and dancing).

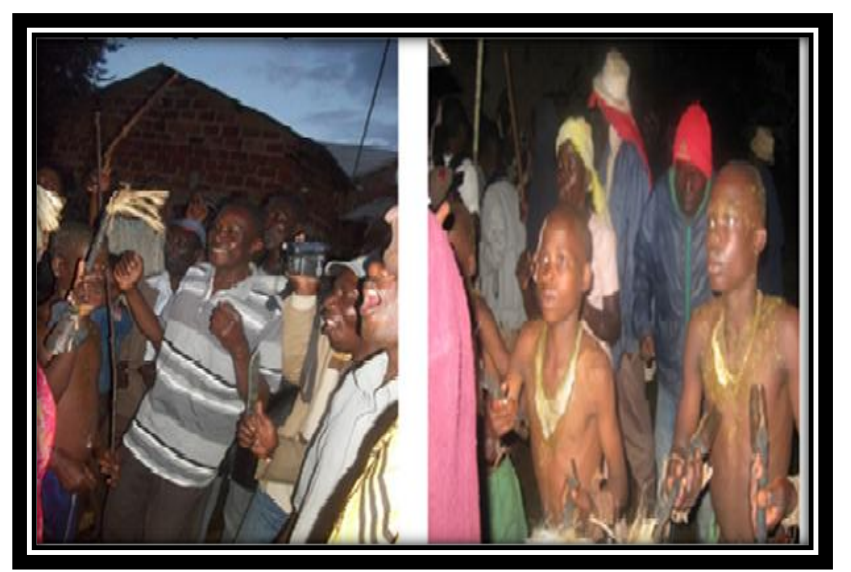

At a crack of the dawn, the boy was escorted to the nearby permanent river which was traditionally called esitosi. During this escort, the boy played chinyimba while the crowd accompanying him sang a peculiar song meant for this purpose (Wagner, 1949: 343). As the procession neared the mudding place, the candidate was instructed to strip naked and also to throw away chinyimba. In the mudding place, a renowned man for his past bravery in circumcision was given the mandate of mudding the entire nude body of the boy (Makila, 1982: 128). A lump of soil was placed on the boy's head into which a leafy grass stem called lusinyande or ututu was mounted (see the photos below of mudding process).

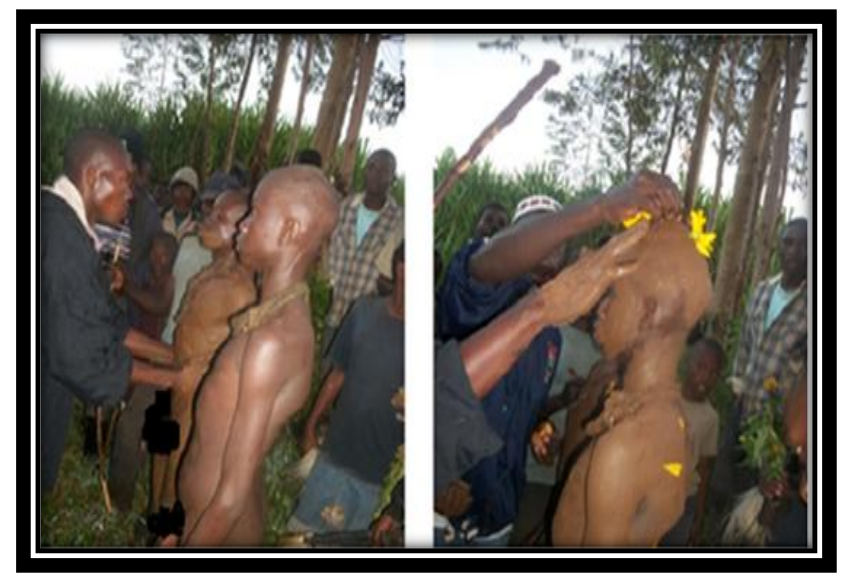

Thereafter, the candidate was then escorted home by the crowd while singing the sioyaye chant. The party followed a different route from the one they had used while going to the river and before the boy reached home, the father met him to encourage him to display unwavering fortitude during the whole process of circumcision without betraying any signs of fear or cowardice (Wanyama, 2017: 72). The paternal aunt (senge) also met the boy while carrying a stirring paddle (kumukango) dipped in the residue of busaa and her main duty was to touch the boy's lips using the cooking stick (see the photos below in which the candidate is escorted home and the paternal aunt runs back after performing a cultural obligation to her nephew).

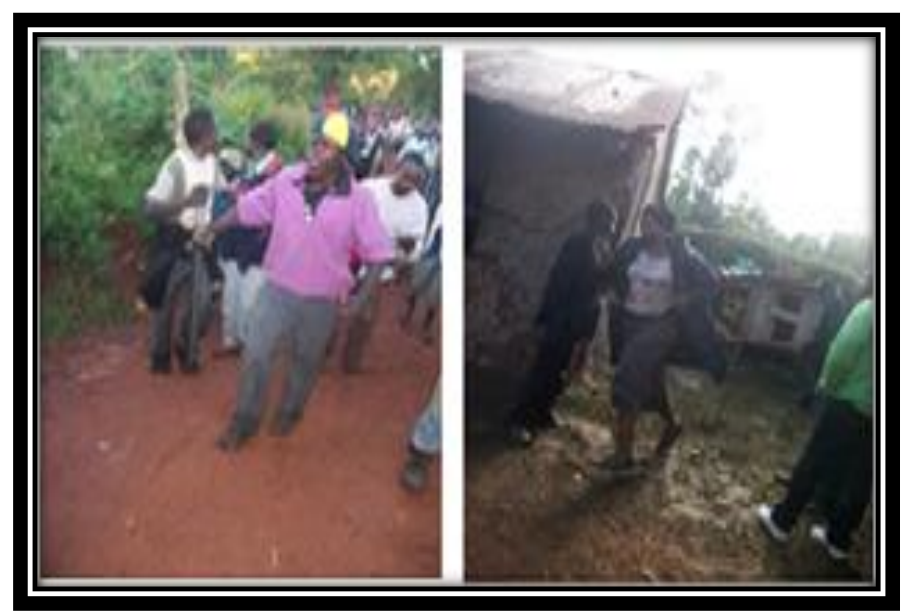

At the father's courtyard (khuluya), elders prepared the circumcision spot that was called etiang' $i$ (singular) or chitiang' $i$ (plural). The boy was carefully led to the etiang' $i$ and without wasting any time, a seemingly excited and impatient circumciser emerged, holding the knife in his right hand (The Nation Newspaper of $11^{\text {th }}$ August 2004). His assistant, traditionally referred to as omutili or omubingilisi swiftly put dust (lipukhulu) made from baked brick into the boy's prepuce (Makila, 1982: 129). The dust enabled the circumciser to have a good grasp of the inner prepuce, which is always very slippery. When the boy successfully went through the ritual, men roared their approval in unison to celebrate the boy's success with war songs. Only then do 
women join in with ululation and dance round the newly initiated (see the photos below of the chitiang 'i, elders leading the candidateto etiang' $i$ and the circumcision surgery in progress).
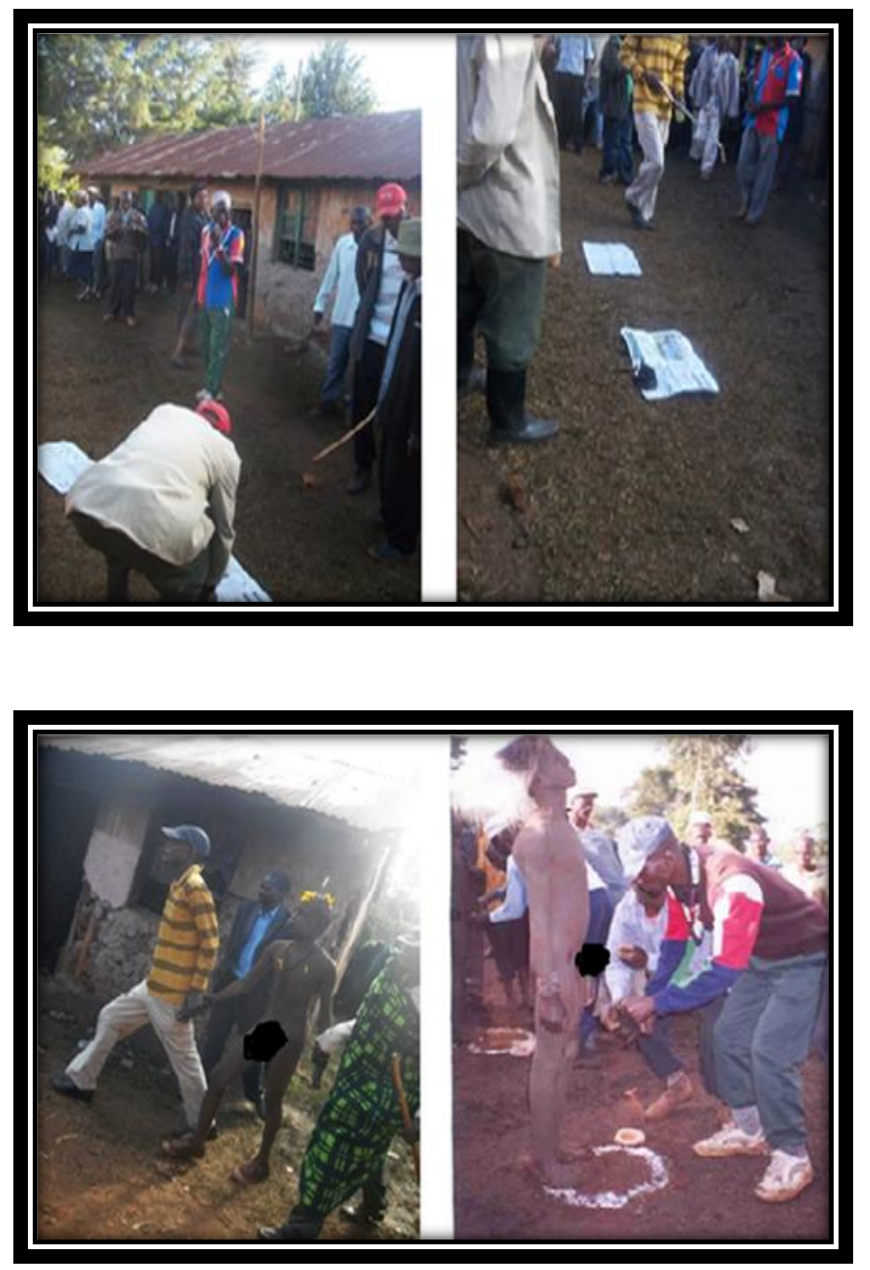

Meanwhile the initiate's mother was supposed to remain secluded in her hut with her legs stretched during the operation only to emerge forthwith completion of the ritual and with other women would then join the jubilation with deafening ululations (See the photo below of the initiate's mother and other elder women seated in the kitchen moments before the boy undergoes the surgery).

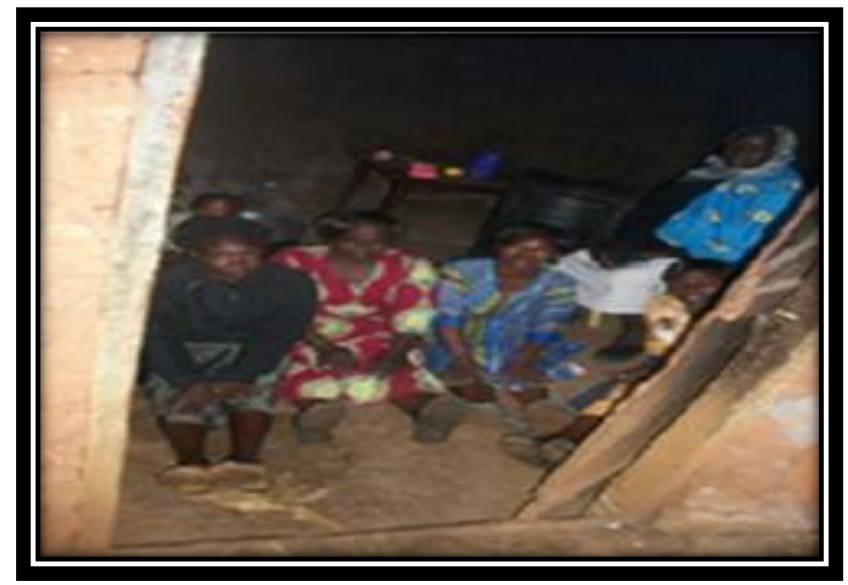

His aunt on the other hand scrapped off the bloodied soil from etiang' $i$ and collected all cuttings from the boy's penis which she wrapped in banana leaves to be disposed discretely. She henceforth was tasked to handle his special diet of meat and ugali or bananas (privileges that come with his acquisition of masculinity). During this period of seclusion (bufulu) "grown up women have to be avoided" (de Wolf 1983: 384-385).

Upon completing the surgery, the boy was ushered into a period of seclusion whose ultimate role was the healing of the circumcision wound. Wanyama (2017: 74) argues that care of the penis during this recovery period was no casual undertaking. Utmost care involving the use of special herbs (enguu) and occasional draining of the liquid formed in the bleb at the tip of the organ (khukhupa enanaki) was a normal routine. This was done under the tutelage of a young man who also instructed the initiate on sexual matters, proper conduct in society and war games.

Note that a very significant cultural rite, traditionally called khubita (Moral counseling), was always conducted during this period (Makokha, 1993: 76-78). This rite was characterized by the boy being told words of wisdom by his circumciser. Other senior members of the family also revealed various family and clan secrets and norms to the boy. Wafula (2003: 84) likens this to modern formal education where lessons are taught to students.

Four months later, the neophyte underwent the very last phase which was traditionally called khukhwiyalula. Khamalwa (2004: 102) notes that the literal meaning of khukhwiyalula is "the hatching rite" where the newly circumcised boy hatched into an adult man ready to take up clan duties and responsibilities. The night before this day, the novice and his company prepared a bonfire in the nearby banana plantation keeping vigil while eating roasted bananas and chicken. It is argued that young girls were permitted to join the initiates for revelry and before dawn, the initiate demolished his makeshift structure made of banana leaves after which he was accompanied to the nearby river (Makila, 1982: 135).

Later in the day, the neophyte was given new clothes or new skins and after putting them on, the boy who by now was 
called omutembete (the fresh and soft one), returned home while chanting a song indicating his new status in the society. When the crew reached home they were served with boiled bananas but eating eventually turned into a mock fight using the same bananas a fighting weapons. Other accounts indicate that the neophyte was expected to demonstrate his prowess as a warrior and his father gave him a spear, a shield, a battle axe, a sword and a club (Khamalwa, 2004: 103).

\section{The growth of IcFEM in Kimilili, impact on Bukusu circumcision}

By December 2012, IcFEM had evolved in Kimilili constituency and its remarkable efforts of transforming the living standards of the local people had been noted (Nyongesa, O.I, 2014). By the same time, the Mission had established its headquarters in Kimilili town, offering employment opportunities to the local people. It had also established a well-equipped medical care unit called "Dreamland Hospital" in Kamutiong'i village, barely two kilometers away from Kimilili town, along the slopes of Mt. Elgon. A nursery school had also been established at the Mission's headquarters while a primary school had been put up near the Dreamland hospital. Being a foreign based ideological organization, the Mission officials had by this time spread new cultural ideas to the local community. These cultures were received with mixed reactions by the local community who were very keen on preserving and reserving their traditional values (Nabisiolo, O.I, 2014). Nevertheless, the concept of cultural globalization has been increasing due to the advancement in transport, scientific and technological innovations hence new ideas were inevitable in the region.

When IcFEM joined the circumcision contest in Kimilili, key cultural elements of the local community that were anchored in circumcision ritual were shaken. This resulted in a state of cultural disequilibrium in which the local community almost surrendering the contest at its own backyard to the new cultural ideologists (Nabisiolo, O.I, 2014). Nevertheless, it is wrong if credit is given to IcFEM alone in the latest circumcision trends that have been observed in the community. Other forces of change in Bukusu circumcision including; Christianity, Western education, intermarriage and the increasing cost of the living standards have contributed to these latest trends (Were, 2012: 12). Again, African cultures have been fought since the inception of colonialism (Moi, 1986: 38) and IcFEM came in as an agent of Western civilization to continue with what the colonial regimes had been started.

IcFEM and male circumcision projects in Kimilili
constituency

Male circumcision is the surgical removal of the prepuce which is always opened and then separated from the glans of the penis. Topical or locally injected painkillers may be used to reduce pain and other related physiological stress_Mutunda, 2009: 33). The procedure is often conducted for religious or cultural reasons and it may also be conducted both for therapeutic and preventive reasons. According to Clayden and Lissauer (2011: 352-353), it is a treatment option for pathological diseases, refractory penis glans inflammation and chronic infections of the urinary tract.

However, male circumcision must be distinguished from female circumcision which isstill carried out in some countries, although it has been universally condemned as a violation of human rights for having serious adverse impacts on women's health, dignity and autonomy(Muraya, 2009: 132).Peristiany (1939: 56) however, argues that each culture has its own individual needs, social institutions and economic systems that influence marriage and initiation rituals observed by such cultured people.

Male circumcision was virtually universal among the Babukusu of Western Kenya, Bungoma County (Egesah and Bailey, 2006: 5). Most young men were circumcised by traditional surgeons but by 2012 families were increasingly turning to medical practitioners for the cut (Nabie, O.I, 2015). Ideally, circumcision for teenage boys was deeply embedded in some parts of Kenyan cultures and it was a rite of passage from boyhood to manhood (Wafula, 2000: 88 and Mutundu, 2009: 31). The Mission's perception on the Bukusu circumcision was that it was a traditional cult which was medically unsafe and full of pagan practices and witchcraft (Nyongesa, O.I, 2014). IcFEM officials therefore aimed at replacing it with clean and clinical circumcision that was conducted by trained medical practitioners.

By December 2012, various forces of change were exerting pressure on Bukusu families to adapt male circumcision rites and practices in ways that were in congruent with the changing demands of their time, resources and social ecology (Egesa and Bailey, 2006: 7 and Were, 2012: 12). Population pressure was one of the forces that caused a shift from agropastoralism to more purely agricultural or salaried and day labour subsistence (Moi, 1983: 19-21). This is also echoed by Khamalwa (2004: 184) who argues that high population density in Uganda had reached such proportions that there were no free fields where circumcision dances could be held.

Again, the need for jobs had resulted in greater emphasis on schooling and in changing residence between rural villages and cities like Nairobi and this in turn put more pressure on attaining sufficient resources to pay school fees and rent. Emphasis on wage labour in the face of limited jobs also changed gender roles as well as intergenerational roles. According to Soita (O.I, 2015) HIV/AIDS forced the Babukusu to re-evaluate all their behaviours and practices which in turn compelled them to bring things that used to be considered mainly in the contexts of culture, tradition and religion into the contexts of health, prevention of infection, education and survival.

Therefore, the Mission rolled out medical circumcision projects at the Dreamland Medical Centre. The first circumcision project was held in 2002 where 1776 boys and men were circumcised in August and a further 800 in 
December from a neighbouring ethnic group. From our oral interviews, it was apparent that the Mission's medical team operated circumcision centres at Chebukaka, Chesikaki, Miu, Mukhe, Sinoko, Bokoli, Mukuyuni, Naitiri, Nzoia, Luanda and Ambichi, where the operation was done for only KSh700 (Soita, O.I, 2015). Each centre had fifteen staff members, including two volunteer circumcisers and four nurses.

In 2006, the cost of a traditional circumcision ceremony ranged from ksh40, 000 to ksh150, 000 ant this was by then one or two years Secondary School fees (Nabie, 2008: 1). It was reported that a man who brought his boys to the Mission's medical team in 2004 commented that his bulls were now safe. Similarly, another man went to roof his house with the money he saved after taking his boy to the Mission's medical team for circumcision. The coming out ceremony traditionally called khukhwiyalula was always conducted in December on the eve of the Christmas school holiday. Instead of spears and shields, boys were given school clothing, books and pens. Note that these were introduced in Bukusuland in 1930's by the colonial government (Kakai, 1992: 147).

Due to the influence from IcFEM's medical team in Kimilili constituency, Bukusu circumcision was taking the Mission's trend because celebrations in many cases were not as elaborate as before and costly as they were in the past, since families cared to save their money for school fees (Soita, O.I, 2015). And more and more Bukusu families were turning to medical circumcision to fulfill their cultural obligation of being circumcised. The main reason for this was that the cost of the traditional circumcision was more expensive because of the need to kill a bull or two, feasting and celebrations that were sponsored by the family. Other reasons included; need for rapid healing to return to school, fear of injury, desire to be modern, alternative ways of expressing manhood such as graduation from school, getting a job and reduced risk of infection, including HIV infection (Eshimuli, O.I, 2015).

According to Nabie (O.I, 2015), medical circumcision had a number of benefits. Key among them was the sterilization of all instruments used for circumcision thus reducing chances of spreading HIV/AIDS from person to person during the surgery (Obel, 1995: 18-24). Circumcision itself reduced the spread of HIV/AIDS as it lowered the amount of soft mucosal surface on the inner foreskin where the likelihood of the uptake of HIV was much greater (Brown and Micheni, 2007: 4).But the manner in which the Babukusu conducted their traditional surgery increased chances of spreading the virus. Again, IcFEM used medically trained clinical officers experienced in circumcision so that post-procedure complication rates were reduced (Soita, O.I, 2015).

This fact is also strengthened and reinforced by Egesah and Bailey (2006: 25) when they posit that traditional circumcisers were rarely called upon to address complications resulting from a procedure performed by themselves. Their role was limited to performing the ceremony and if a complication from the traditional circumcision needed to be addressed, a different person was called upon and this could have been a local village shaman, a "traveling nurse," who provided dressing and antibiotic powder, or a certified nurse or Clinical Officer who lived nearby and was willing to go in the villages. In other cases, the family took their boy to a health facility where he was treated by a qualified medical practitioner. In these cases, the costs of the treatment went high because the practitioner was addressing a problem created by someone else hence charges were higher. In the case of one young man who was circumcised by unqualified traditional practitioners for $400 \mathrm{KShs}$ and then taken to a Health Centre or a District Hospital for re-surgery, the total charges amounted to $3200 \mathrm{KS}$ (Soita, O.I, 2015).

The Mission's medical teams scored a plus in such cases. Its members recognized abnormalities such as hypospadias and referred for correction. In the hands of traditional circumcisers however some of these boys were permanently mutilated or even died (Nabie, O.I, 2015). The Mission's evangelical team also condemned the traditional surgery because it was associated with magic and witchcraft. Financially, traditional rites were associated with parties for extended families, neighbours and friends. According to Nabie (2008: 1), the cost of circumcision for each family was between ksh40, 000 and ksh150, 000 and this was a huge sum of money in a poor community. In most cases, this resulted to children being sent out of schools thus escalating deep poverty in the area. IcFEM charges were low thereby saving families large amounts of money which became available for education, food and housing among other basic requirements.

It was also observed that the Babukusu and other societies that practiced traditional circumcision underwent ridicule for adhering to practices that were perceived by other communities in Kenya and elsewhere as primitive, wasteful of human resources and exhibiting disregard for the rights of children and adolescents (Namungu, O.I, 2015). On moral ground, the words of traditional ceremonies actively encouraged boys to prove their manhood through sexual intercourse. The results were numerous teenage pregnancies resulting to girls leaving schools and rarely returned.

Traditional surgery also encouraged considerable alcohol consumption which enhanced moral decay in the society. Other disadvantages as pointed out on traditional circumcision include; much pain, fatigue experienced during long period of ceremonies, distraction from school, destruction of family resources and property, rowdiness, seduction and sex (Banda, O.I, 2014). Surprisingly the Mission officials recognized some positive aspects of the traditional circumcision (Egesah \& Bailey, 2006: 26-27). These include; giving advice to the boy in his role in the society and his responsibilities as a man and husband, adherence to the norms in the society, sense of community and solidarity with peers and gifts and rewards that accrued to the boy and his family from relatives and friends (Mutunda, 2009: 31). 
In a society where circumcision was universal (Egesah \& Bailey, 2006: 5 and Makokha, 1993: 73), young people had no choice but to be circumcised. Under such conditions, they had a right to safe services and to be able to make informed choices about how the procedure was to be performed. It was also observed that unclean conditions and inadequate knowledge about how to care for the wound was the motivating factor behind the Mission's venture into the provision of safe and clean circumcision to the local people. As observed by Soita (O.I, 2015), penicillin powder was commonly applied to the wound but the powder became caked in the wound, slowed healing which resulted to thick scarring and in some cases discoloration (Nyongesa, O.I, 2014). Bandaging often consisted of soiled cloth or gauze that was applied repeatedly and the wound often went many days without cleaning and when the bandage was removed, it reopened the wound.

Inadequate knowledge about the post-operative care was another concern of the Mission's medical team. Despite having gone through it themselves, senior Bukusu males appeared to have inadequate knowledge on the part of fathers and older men about the wound care or detection of complications (Nabie, O.I, 2015). The prevailing circumcision approach to such complications seemed to be to wait and see and hope for the best. It was also observed that older men themselves went through difficulties such as excessive pain, swelling, slow healing and sometimes lack of erection but the threshold for them determining when a boy needed medical care was very low. In addition, families were likely to incur the costs of follow up care. Hence, they attempted to address complications by themselves or with help from indigenous healers who were not knowledgeable.

Having conducted a field research in the region, the Mission's evangelical and medical teams were also concerned about the early sexual activity by boys circumcised traditionally (Sankey, O.I, 2015). Additionally, a sample of young men was sexually active at early ages. The median age of sexual debut was between fourteen and fifteen years and the odds of having had sex before circumcision were three times greater for those circumcised traditionally than those circumcised medically (Namungu, O.I, 2015). Again, those circumcised traditionally were more likely to have resumed sexual activity 60 days after their circumcision than those who were circumcised medically.

After a number of campaigns led by the evangelism and medical teams of IcFEM, it was apparent that preference for medical circumcision was the only option to bring light to the Bukusu community. As time went by, it was understood that majority of the Babukusu preferred their sons and brothers to be circumcised by medical practitioners, citing advantages listed above than traditional circumcisers (Biboko, O.I, 2015). However, two most salient reasons should be emphasized. They are; lower cost of the operation and the safety. This notwithstanding, a prevailing sentiment was a general sense that traditional circumcision was backward, resource wasteful and no longer relevant in an era when families were struggling to get school fees.

Much emphasis was made on western education to enhance employment opportunities in a competitive economy. The partying, the rowdiness and the distraction of education that accompanied traditional circumcision, combined with pain and the suffering experienced by the boy reinforced the reluctance to spend limited family resources on an act that could be achieved quickly and privately at minimal costs. There was also the sentiment that traditional circumcision was anti-Christian, primarily because of all the rituals and ceremonies involved (Nabiswa, O.I, 2014).

Whereas women expressed similar sentiments against traditional circumcision practices most often, older men in rural areas more likely preferred to stick to the traditions of circumcising in villages with all the culturally appropriate fanfare. Nevertheless, most of the Babukusu preferred circumcision to take place in medical settings. These are sentiments of IcFEM director, Mr. Nabie (O.I, 2015), contrary to Wambani (O.I, 2014), a traditional surgeon who asserted that the prospect of social pressure and possible stigmatization was a powerful deterrent against change campaigned by IcFEM's medical team. Males in most cases were fearful of being stigmatized in their community for having not gone through the traditional rite. Women seemed less concerned about this but they were more concerned about the safety of their sons (Namwenya, O.I, 2014).

Upon uproar and cries from the local people for having intruding into their traditional circumcision, IcFEM strongly defended itself arguing that it was not trying to change the traditional practice of circumcision in the community but rather, it was tackling the traditional cult of circumcision, which was medically unsafe and full of pagan practices and witchcraft (Sankey, O.I, 2015). The Mission aimed at replacing the traditional practice with clean and clinical circumcision by trained medical practitioners.

\section{Impact on the traditional practice of circumcision}

According to Haviland (1975: 419), all cultures change at one time for several number of reasons. Haviland maintains that contact with other people may lead to the introduction of foreign ideas thus bringing about change in the existing values and behaviours. Nabie (O.I, 2015) likens this cultural evolution to a vehicle which transports people from one generation to another. Should the vehicle break down before people reach their destination then, another vehicle will be used for them to accomplish their journey. The unfortunate observation according to Nabie is that people think they should serve their culture contrary to the initial intention of the same culture which is serving them. Nabie argues that Bukusu culture is not solving numerous challenges facing the society in general and that cultures of our grandfathers will not be the same cultures for our grandchildren many decades to come. 
An analysis of traditional practice of circumcision among the Babukusu and modern practice of circumcision conducted by IcFEM and other medical units revealed disparities in the practice of the ritual. IcFEM worked hard to shorten the elaborate and tedious stages followed by the Babukusu during circumcision. The Mission's medical team conducted circumcision any time of the year to boys of any age (Nasimiyu, O.I, 2014). Nabie's men encouraged the community to shorten the elaborate procedures of conducting the surgery and to a larger extent they succeeded in convincing a good percentage of the Babukusu to accept the circumcision they offered.

With regard to the preparations that took place before circumcision, IcFEM took less concern on prior preparation before the real surgery. It demonized beer brewing and drinking. Nabie's officials also condemned the night practices by boys in readiness for khulanga which started shortly before August (Wambani, O.I, 2014). During these night practices, rampant sexual activities featured contrary to the biblical teachings which forbid illicit sex. The Mission's medical team condemned all these practices and the government supported this move. Local provincial administrators were instructed to arrest boys who engaged in night practices while parents on the other hand were cautioned against releasing their children to attend such unnecessary events (Kunusia, O.I, 2014).

IcFEM officials also condemned the whole process of khulanga using chinyimba. As noted earlier, it involved candidates moving around the village while playing chinyimba to invite relatives and friends for the ceremony (Makokha 1993: 73). This was a waste of time that could have been used in productive activities to enhance their economic status. During these movements, the boy was left fatigued and was always insulted, beaten and ridiculed (Nyongesa, O.I, 2014). This was viewed as an irrelevant stage that had no value at all to the boy. Due to the influence from IcFEM and other critics of the Bukusu circumcision, the community took an approach seemingly deviating from the original traditional course.

IcFEM and other pro-medical circumcision stakeholders also criticized beer brewing process. People who took alcohol were seen as sinners and any cultural practice that involved beer was condemned (Namungu, O.I, 2015). During beer brewing (khuchukhila), some cultural norms were performed and according to the evangelical team of the Mission, such cultures were associated with ancestors and spiritual worlds which IcFEM related to idol Worship. This was condemned in the Decalogue which Moses was given by God to deliver to the Israelites during the Exodus. When going to fetch water in the river, the candidate carried a pot on his shoulder. When he arrived home, a two-mouthed pot was placed outside the house and the water fetched from the river was poured in this pot. This process was condemned because it was full of cultural symbolism that was believed to be idolatry. For this reason, some families opted to conduct traditional circumcision without beer. They prepared tea and other food on that night of khuminya, deviating from the initial circumcision culture of the Babukusu (Khalaba, O.I, 2014).

The visit to the maiden uncle by the candidate was another point of concern by IcFEM officials. They strongly condemned the carrying of the meat by the boy around the neck. Slaughtering of a bull in the maternal uncle's home was associated with offering sacrifices to ancestral spirits which is idolatry in the Christian perspective. Banda (O.I, 2014) argued that it was a waste of time and resources which could have been made useful in some other productive projects. Carrying of the meat in the neck and mocking of the initiate was seen as torture thus contravening Article 25a of the Constitution of Kenya (2010) which guarantees all Kenyans freedom of torture, cruel and inhuman or degrading treatment.

The application of cud to the boy's body which was culturally meant to make the boy courageous (Wagner, 1949: 342) was seen as a form of devil worship. Consequently, massive exodus of Bukusu boys from traditional to medical circumcision had been witnessed by December 2012. The Mission evangelical team spread Christian gospel to the local people and majority of them accepted the call. Hence, most of them opted to skip the visit to the maiden uncle's home. However, they still embraced traditional circumcision. That is why they would still accept to face the painful knife the following morning.

The entire process of khuminya had also experienced an overhaul by December 2012. The process was condemned on medical grounds because it exposed candidates to extreme cold temperature that was likely to cause respiratory diseases such as asthma and pneumonia. The idea of placing a piece of meat from rumen around the neck of the boy for the whole night was also condemned for being unhygienic (Mwambu, O.I, 2014). Again, sexual immorality portrayed during the night of khuminya went contrary to the biblical teachings of abstaining from adultery and fornication.

During the night, obscene songs were sang without any consideration of young children who were around. Therefore, khuminya was criticized for encouraging sexual immorality. Since its establishment, IcFEM evangelical team thus endeavored to change this practice and to some extent, it succeeded. A systematic decline ofkhuminya by December 2012 had been observed. Many families were converted to Christianity resulting to a drastic decline in the observance of the night dancing and singing. To achieve this, the Evangelical team of IcFEM associated khuminya with witchcraft, wizardry and the worship of ancestral spirits (Sankey, O.I, 2015). Most families therefore preferred waking up early in the morning to circumcise their sons. Others opted for hospital circumcision instead.

The mudding place was another point of conflict between the Mission's evangelical team and the Bukusu community (Wambani, O.I, 2014). The sacredness emphasized on the ebitosi was interpreted to mean source of evil in the Bukusu circumcision. This explains why the team conducted prayers 
at Nakhobano mudding place near Friends School Kamusinga in July 2010. Their point of concern was that applying mud on the nude body of the boy was unclean. Walking naked while going home was also immoral because boy's genitals were exposed to the public and this was seen as inhuman (Nasimiyu, O.I, 2014). Comparing this with the way IcFEM conducted the surgery, the Mission's medical circumcision was much safe and secretive. It did not expose the boy to any torture or shame of walking naked to the circumcision ground (Soita, O.I, 2015). This argument made sense to the Babukusu and some of them resorted to hospital circumcision.

The real act of circumcision among the Babukusu was also a centre of focus by the Mission's medical officials. The process took barely a maximum of ten seconds (Wagner, 1949: 350) but it's elaborate and many stages was what the team argued against. The process had a negative economic implication to families involved because it resulted to thewaste of important time which could have been used in other productive activities. Indeed, most of the Babukusu saw the importance of the Mission's officials in shortening the very long process (Nyongesa, O.I, 2014). Occasionally, the aftermaths of traditional circumcision were disastrous. Sometimes, boys died due to excessive bleeding after wrong cuts were made on their genitals. Again, traditional circumcisers did not correct any deformity on the sexual organ of boys which the medical team of IcFEM did. From such scenarios, the medical team of the Mission was of great help in addressing such challenges (Banda, O.I, 2014).

Traditional African circumcision was always done without the benefit of anesthesia which often left the boy to endure pain (Magesa, 1997: 96 and Mutunda, 2009: 33). This contradicted the Mission's medical circumcision which injected boys with anesthesia hence the operation was without pain. The use of dust by traditional circumcisers was proved to be unfit. It is argued that dust (lipukhulu) contains tetanus which is a killer disease. In other words, Bukusu circumcision was unclean and prone to disease that the Mission's medical team endeavored to stop. With evangelism by the Mission, the Bukusu community had a paradigm shift towards safe, "godly" and clean medical circumcision which was offered by IcFEM's Dreamland Medical Centre (Soita, O.I, 2015).

The treatment of the circumcision wound was another aspect of circumcision culture where the Mission's medical circumcision scored. Traditionally, the Babukusu used a local herb called епяии (Microglossapyrifolia) (Makila, 1982: 131). The preparation of this herb attracted sharp criticism even before IcFEM came in. The manner in which the herb was harvested and prepared for use was a point of concern. It is argued that herbalists conducted some spiritual actions of communicating to the herb before being harvested. The essence of such action was to awake the medicinal component of the herb being harvested (Mwambu, O.I, 2014). This, according to the evangelical team was a form of idol worship which contradicted the Christian doctrine of monotheism (Exodus 20: 1-3). Nevertheless, dried leaves from the herb were usually crashed to produce a black powdered substancewhich was applied on the wound and bandaged using a leaf from the same herb. Normally, the application of this herb was very painful and this subjected the boy to unbearable pain and suffering (Khalaba, O.I, 2014).

The advent of Western medication in Bukusuland led to the introduction of hospital medicine and real bandages to replace the old system of using the traditional herb (Wasike, O.I, 2014). However, IcFEM medical team played a key role in inculcating medical treatment to the wound. Before applying treatment to the wound, medical cleaning was done using disinfectants such as spirit and Dettol. Thereafter, the wound was well dressed for quick recovery. Due to this, there was cultural syncretism where candidates circumcised traditionally were treated using modern medicine. There was also massive exodus by the Babukusu from using traditional herbs in treating the wound to medical approaches that were hygienic. Earlier on, candidates nursed the wounds even for three months but the advent of Western medication reduced this to barely three weeks (Makhanu, O.I, 2015).

The post initiation ritual of the Babukusu traditionally called khukhwiyalula also received massive criticism from IcFEM. Traditionally, boys were ushered into adulthood culturally as discussed earlier. On that night of the ritual, boys slept in a banana plantation before going to the river the following morning (Wagner, 1949: 364). New clothes were brought to them and when they went home, a ritual involving a mock fight using boiled bananas was staged (Makila, 1982: 136).

However, IcFEM initiated a post initiation ritual that was based on Christian principles. Candidates assembled at the Mission's centre for two to three days where moral counsels were told to them (Chikati, O.I, 2014). The type of moral counsel and words told to the boys had a wide disparity with what was told to their fellow neophytes when conducting post initiation ritual in the traditional setup. Spiritual and educational emphasis in the boy's future life after circumcision was also inculcated to the boys during this time.

Abstinence from sexual intercourse at that time was discouraged contrary to the post initiation ritual in the Bukusu community which advocated for the experimentation of their sexual organs after circumcision (Parrinder, 1976: 94-95). The Mission's evangelical team offered lessons that enhanced the boy's moral uprightness in the society. Such lessons had biblical concepts most of which most deviated from the Bukusu traditional practice of circumcision.

During these seminars, boys were encouraged to get formal education in order to acquire white collar jobs (Moi, 1983: 172-173). Bright boys from poor backgrounds were given bursaries to meet their school fees and other expenses. Indeed, a number of boys benefited from the Mission's educational bursaries since the establishment of the scheme. Concisely, IcFEM had a great role in the revolution of the traditional practice of circumcision. Its main aim was to replace the traditional circumcision which was unsafe and unclean with a 
safer and cleaner medical circumcision. A steady decline in the practice of traditional circumcision was, therefore, witnessed.

\section{IcFEM, socialization and community interaction}

In many African societies, cultural groups have developed and continued to carry out initiation practices such as circumcision which provided male children with a passage from boyhood to manhood (Mutunda, 2009: 31). During such initiation practices, boys formally attained manhood status in addition to receiving lessons in things that men needed to do in order to be considered masculine. More fundamentally, initiation played a key role of socialization, community interaction and what Moi (1986: 73) calls cultural cohesion and family life.

The Bukusu community is social by nature. By social, we refer to the manner in which people in this community interacted and acquired the social norms of the society. In most cases, these interactions were classified according to the stratus of age, gender and the type of roles played by individuals in the society. The manner in which people of the same gender interacted was well mapped out in the social norms of the community. Teenage girls interacted while performing their normal chores such firewood collection, fetching of water among others. Teenage boys on the other hand interacted during their usual duties of looking after their family livestock (Spear, 1981: 74-75) and wrestling contests. However, circumcision period provided a fertile ground upon which socializations and interactions of all strata of people occurred (Wasambo, 2014: 118). In this perspective, the interference of the Bukusu circumcision would be an infringement on the interactive platform of this community.

The whole process of the initiation ritual from the initial stage to the very last one in Bukusu community was very interactive in nature. The usual movements of candidates from one homestead to another socialized people. The jovial singing and ululations made on arrival in homesteads also provided avenues of interaction (Makhanu, O.I, 2015). Brief sessions of dancing and singing in a particular home visited by the candidate were forms of interaction. Perhaps, this explains why Wanyama (2005) maintains that "Bukusu circumcision ceremony (sikhebo/sisingilo) entails performance of circumcision music by almost all the participants. This makes the ceremony a social event."

The climax of it all came during khuminya where people of all walks of life in the Bukusu community converged for a night for the circumcision ceremony (Makila, 1982: 127). Singing, dancing, feasting, drinking beer and other forms of merry making were done on this night. During this night therefore socialization took place. Mingling and interaction of people from different families and ages took precedent against any other thing. During the post initiation ritual which was conducted close to four months after circumcision, socialization also took place. Beer drinking and feasting done on that particular day of khukhwiyalula also enhanced socialization of the community (Wambani, O.I, 2014). In summary, circumcision process played a major role of socializing initiates into the community. It was the main agent of socialization where the youth were given a chance to mingle freely with other members of the society.

However, Bukusu circumcision slowly lost its cultural value of socialization especially with the emergence of organizations such as IcFEM. It is worthy to note that criticism on Bukusu circumcision did not emanate only from the actions of IcFEM. The government on many occasions attempted to disrupt Bukusu circumcision by extending the academic calendar into the month of August (Wasilwa, 2006). However, traditional circumcisers opposed such moves and in most cases some students skipped a week or two towards the end of the second term to be engaged in early preparations for their initiation. When IcFEM came in, it condemned and campaigned for the outlawing of this practice. The Mission officials emphasized on Western education as the main agent of socialization. At school, Western mode of socialization was imparted into the youths contrary to the type of socialization encountered during the traditional initiation ritual (Nabisiolo, O.I, 2014).

Emphasis on education by IcFEM reduced the circumcision ritual as a mere physical cut on the boy's penis with no significant socialization role in the community. The mission evangelical team did not emphasize any socialization as envisaged by the Bukusu traditional circumcision (Khalaba, O.I, 2014). It was argued that sexual immorality among teenagers took centre stage during khuminya. Thus, it encouraged pre-marital sex which eventually led to premarital pregnancies and increased the spread of STI's such as HIV/ AIDS among others (Muller et al, 2009).

However, it can correctlybe argued that the pre-marital sex that took place in Bukusu community, either as an outcome of khuminya or other causes was rare in the pre-colonial setup of the Babukusu. This was attributed to the foreigners who infiltrated Bukusuland and took such opportunities from the local community to commit such irresponsible sexual behaviours. Otherwise, most circumcision ceremonies that were conducted without the influence of such uninvited guests were always done safely without such social evils (Nabiswa, O.I, 2014). Bukusu elders in such moments were always vigilant and they supervised the socialization of the youth.

Due to this challenge, many families resorted to modern circumcision spearheaded by IcFEM's medical team. Such families saw no socialization value of the traditional ritual and they opted for Western education as the key agent of socialization in the lives of their children. A keen scrutiny of such boys however, revealed the opposite of what IcFEM medical and evangelism team preached. In many occasions, cases of lesbianism and homosexuality were reported in the same gender boarding schools within Kimilili constituency.

Among the Babukusu, cases of such kind never existed and during the initiation periods, the youth were inducted into adult sexual life of the opposite gender. For this reason, it was 
a very rare occurrence to realize irresponsible sexual behaviours such as lesbianism and homosexuality among the Babukusu. By 2012, the act was very rampant in secondary schools found in Kimilili constituency (Wanyama, O.I, 2014). A famous girls' school at the backyard of IcFEM was in the Kenyan media in 2012 because there were rampant cases of lesbianism in the school. If critical follow ups were made, it would not be surprising to unearth that majority of boys who were circumcised medically became victims of such irresponsible sexual behaviours.

IcFEM and other critics of Bukusu circumcision did not provide clear socialization platforms where the youth systematically realized their sexual orientation (Wambani, O.I, 2014). At the end, social decay in the society was witnessed. The Mission officials should therefore take the biggest share of the blame for the moral decay related to sex that was witnessed in schools as agents of socialization. This was because the Mission officials together with other organizations championed for hospital and medical circumcision without realizing and putting in place control measures to such evils in the society.

According to Khamalwa (2004: 140), the induction of the youth into adulthood played a key role of the traditional circumcision among the Bagisu of Uganda. Usually, boys were circumcised at the age of 18 to 24 years and at this age, they were ripe for marriage hence circumcision introduced them into a life of responsibility. Without its consummation in marriage, circumcision thus remained incomplete (Magesa, 1997: 100). Wanyama (2006: 27-28) contends that Bukusu circumcision ritual was traditionally a test of maturity and preceded marriage. During the entire process of circumcision, initiates acquired values associated with parenthood.

In contrast however, IcFEM evangelical team argued that circumcision to boys could be conducted at any age. Even a one day old boy could be circumcised similar to the Jewish practice which subjected the boy to the cut eight days after birth (Nyongesa, O.I, 2014). With such upsurge from IcFEM, Bukusu circumcision lost its role of testing maturity and it did not necessarily precede marriage. It was at the risk of losing its religious value and becoming gradually secularized as the focus rested more on the physical rather than the social functions of the ritual. This argument on the age of undergoing the surgery led to the detrimental practice of Bukusu circumcision because many people circumcised their boys at tender ages hence demeaning the adulthood responsibilities bestowed to boys during circumcision (Naulikha, O.I, 2014). Usually, boys at tender ages were still minors who new nothing about moral and adulthood values.

By 2012, circumcision was no longer a gate way to marriage but rather a mere physical cut with very meager significance to marriage. After circumcision, emphasis was put on Western mode of education in which the youths were urged to complete their studies and secure white-collar jobs (Moi, 1986: 41-47). This implied that one could stay close to twenty years after circumcision before thinking of marriage. Marriage immediately after circumcision was discouraged by IcFEM officials and emphasis was placed on the acquisition of formal education.

According toKhamalwa (2004: 208-209) a similar scenario was observed among the Bagisu of Eastern Ugandaand the introduction of formal education transformed the ages at which circumcision occurred. Traditionally, boys were circumcised at the age of 18 to even 24 years but education made young boys of up to 11 years to be circumcised. This implies that traditional circumcisionlost its culturally intended function of marriage. Late marriages as a result of extended periods of studies were witnessed and they had a number of challenges which were rare in the traditional Bukusu community (Banda, O.I, 2014). These challenges included; divorce, adultery, family feuds, misappropriation of family resources, neglecting of children, late parentage and sometimes celibacy.

Wrangles and feuds which were exhibited between those circumcised in hospitals and those circumcised traditionally demeaned the cultural value of the age-set system in Bukusu community. According to Kusimba (O.I, 2014), almost 90\% of the Bukusu young men did not know their respective circumcision age-sets by December 2012. This represented the number of the youths who underwent hospital circumcision and did not have the interest of being informed about traditional circumcision. The value of age-set system (bakoki) was always embraced during traditional circumcision and in most cases the initiates were cognizant of what was taking place (Makila, 1982: 123). However, this was not embraced at all especially by boys who followed the preaching and the demands of IcFEM evangelism and medical teams.

The inception of hospital circumcision in Bukusuland created a cultural conflict that became a source of discomfort and disharmony in the community. According to Mutunda (2009: 33), true Bamasaba men should undergo traditional surgery where anybody can witness the operation. This was a similar case with the Babukusu believed that doing away with traditional initiation would change the rightful and cherished cultural heritage that was earned meritoriously. Mango, the reformer of the current circumcision practice among the Babukusu will be relegated to a mere historical figure in the history of this community should traditional circumcision be faced out successfully. That is why there existed a cultural conflict with those circumcised in hospital being rejected and always scorned by those who were circumcised traditionally. They were often referred to as kiekhulupao and this is a derogatory term that was used to refer to cowards who feared facing circumcision knife and opted for hospital circumcision instead (Khalaba, O.I, 2014).

Normally, such khulupao people were regarded as boys and they earned little or no respect at all from the society. Occasionally during circumcision periods, the khulupao 
neophytes and their traditional counterparts would not meet and if they met, the khulupao ones were beaten by their home circumcised counterparts. They even sang the sioyaye chant to the khulupao candidates to ridicule them. (Musikiti, O.I, 2014). Others forcefully stripped naked the khulupao neophytes and attempted to smear mud on them to imitate the khulonga process observed in traditional circumcision. In such circumstances, the khulupao neophytes were not regarded as age-sets with their fellow home-initiated novices. A sarcastic song was composed explaining how a boy circumcised in hospital should call his mother bakoki (Masika, O.I, 2014). In the same song, the boy was depicted to be a laughing stock in the communityto the effect that women were circumcisers in hospitals unlike in traditional surgery where circumcision was exclusively reserved for men.

It should be acknowledgedthat khulupao circumcision did not begin with IcFEM in 1988. It is not a creation of IcFEM but rather a colonial evolution concept which Nabie's Mission intensified. Hospital circumcision dates back to the colonial period in Western Kenya where mission centres such as Kaimosi and Yala offered the said medical surgery(Kakai, 1993: 175-179 and KNA, MISS/54/212: 1919). The independent government took it up from where the colonial regime left hence hospital circumcision kept on evolving and taking new trends. It got support from the government and as time went by medical surgery won the hearts of many Bukusu people.Western education was also embraced by Africans (Tignor, 1976: 111-113) and this also catalyzed the spread of the khulupao circumcision in Bukusu community.

By 1988, cultural conflict was already in place with regard to circumcision. The Mission entered into a conflict it did not start and its attempts of offering medical circumcision in Kimilili worsened the already worrying situation between the two proponents of circumcision. To enhance their objectives, the Mission gave incentives to those families who allowed their sons to be circumcised medically. Such boys were given academic scholarships to further their studies. They were also given post-initiation medical care and follow ups were made to ensure their well-being. Traditionally circumcised boys were side-lined by the Mission officials (Murutu, O.I, 2014). They were not given such incentives, a scenario which escalated the already existing circumcision tension in the community.

Determined to completely transform the traditional surgery, IcFEM went ahead and conducted fasting and prayer sessions at various mudding places within its vicinity. The motive behind this was to drive out circumcision demons within the mudding places (Namungu, O.I, 2015). The very first prayer session was held at Nakhobano mudding place which is at the backyard of Dreamland Medical Centre and Friends School Kamusinga. The Mission evangelical team camped at the mudding place, singing and praying for that land. This was a breach of Bukusu cultures because the mudding place was a sacred place in the community and not everyone was allowed to go close to that holy swamp (Wambani, O.I, 2014). This happened in July 2010 few days before the beginning of the ceremonial circumcision practice. This initial attempt by IcFEM made the Bukusu elders to come out strongly and condemn the Mission's act of poking into their culture. They called upon those residing near the mudding places to be very vigilant to ensure that the Mission did not succeed in their agenda.

This action by IcFEM opened a new chapter of discomfort between the Mission officials and the Bukusu cultural conservativists. By championing for boys to be circumcised at the Mission hospital, many of the Babukusu believed the action was enhancing devil worshipin which the blood that was shed during hospital surgery was used to feed their devils (Khalaba, O.I, 2014). The Mission in general was thus in great cultural controversy with the Bukusu community which overlooked the positive aspects and contributions made by the Mission. The Bukusu Cultural Heritage Association and its 2,000 affiliate traditional circumcisers strongly opposed the Mission's agenda, urging Mr. Nabie and his team to keep off the community's circumcision affair.

For this to be achieved effectively, Manguliechi, one of the leading custodians of the Bukusu culture by then was involved. He was seen one night going around IcFEM compound in July 2006 while throwing charms and spells at the Mission offices (Nabie, O.I, 2015). Further attempts by the Mission's evangelism team to proceed with their prayers at Kamasielo mudding place was strongly opposed by the local people (Wambani, O.I, 2014). They took their weapons and dared the Mission officials to step into their sacred land. Sikhendu mudding place was also guarded jealously by the community to avoid the contamination that was to be brought by the Mission officials (Kunusia, O.I, 2014).

\section{Circumcision, IcFEM and the Bukusu economy}

In traditional Kenyan societies, societal fabric and systems of operation stressed the communal role without inhibiting the productivity and the creativity of the individual (Moi, 1986: 9) but the Mission's entry into circumcision venture in Bukusuland had its share of economic outcomes to the local community which were detrimental to Moi's observation. According to Wafula (2003: 66), the economic mainstay of the Bukusu community since the pre-colonial period was agriculture. However, population pressure in the region led to drastic decrease in food production due to land fragmentation for settlement after independence. The region also attracted people from other ethnic communities who settled in Bukusuland to further compound the problem of congestion.

By 2012, it was rare to find a Bukusu homestead with a large herd of cattle as it was the case one hundred years ago. The growing of cash crops introduced during colonial period also dropped because people preferred growing food crops for subsistence consumption. It was only a few individuals who managed to produce surplus food. The destruction of forests and guarding of wildlife by the Kenya Wildlife Services also negated hunting which was an economic practice of this 
community (Spear, 1981: 731 and Moi, 1983: 150). With these food problems, IcFEM found a fertile ground upon which its opposition to Bukusu circumcision was based. Under normal circumstances however, Bukusu families harvested enough food that lasted even for two seasons (Makila 1982:61-63). They also reared large herds of livestock hence sacrificing two or three bulls during circumcision seasons was not an issue.

The current formal education that is very costly never existed in the pre-colonial setup of this community. Generally, the cost of living was relatively cheap and it was rare for one to miss food. Nonetheless, the change of the state of affairs with the advent of modernity in the region led to the infiltration of foreign ideologies and practices that greatly undermined the economic status of the Babukusu (Banda, O.I, 2014). Such ideologies challenged the economic viability of Bukusu circumcision resulting to a systematic paradigm shift from the traditional practice of this ritual to modern medical circumcision. This was however not an easy task to the visitors according to Fanon (1963: 167) who noted that preceding generations in the underdeveloped countries resisted the work of cultural colonialism.

The underlying economic viability and the arguments about Bukusu circumcision marked the entry point of IcFEM in the provision of medical circumcision to the local community at a cost of KShs 700 in 2002 compared to the cost of the traditional circumcision which was at least KShs 40,000 (Nabie, 2008: 1). Wanyama (O.I, 2014) observes that a very luxurious traditional circumcision ceremony cost was as high as KShs 150,000. If simple arithmetic was done by December 2012, a mature bull in Kimilili constituency was traded at a cost of KShs 35,000 while a $90 \mathrm{Kg}$ bag of maize at a cost of KShs 5,000. A luxurious circumcision ceremony required at least three bulls thus translating to KShs 105,000 . For a family to brew enough busaa for the ceremony, at least five $90 \mathrm{Kgs}$ bags of maize were required, translating to KShs 25,000. Other miscellaneous expenses amounted to around KShs 20,000 thus the sum total of a luxurious traditional circumcision reached up to KShs 150,000 (Chikati, O.I, 2014).

From an economic point of view, it is quite unreasonable to spend KShs 150,000 on a service whose market value is KShs 700. According to Eshimuli (O.I, 2015), that was exactly what majority of the Bukusu families in Kimilili constituency were doing. Due to emphasis placed on the traditional surgery, many families spent considerable portions of their income on the ceremony at the expense of other basic necessities like good housing and clothing. Other families did not reserve enough food for a whole season due to a one-day circumcision event. More surprisingly, cases of families spending up to KShs 150,000 on the circumcision of a candidate but failed to meet school fees for the same boy were reported. According to Mr. Nabie (O.I, 2015), such families had misplaced priorities prompting his Mission to take up the sole mandate of enlightening the local people to reconsider the order of their needs. This prompted IcFEM to roll out circumcision projects to the local people at a very affordable cost.

'Time wasted can never be recovered.' This is a phrase that encourages people to utilize their time appropriately. IcFEM capitalized on this proverb to criticize many Bukusu families for wasting close to two weeks on an operation that lasted barely ten seconds (Lesley, O.I, 2015). If one family wasted two weeks on circumcision, then the entire Bukusu community wasted considerable number of weeks on circumcision. This valuable time could have been channeled to other productive economic projects. Considering the number of people involved in a single ceremony, much labour was indeed wasted on the ceremony. Boys boycotted schools for few weeks, a factor that affected their studies negatively (Biboko, O.I, 2015).

From this perspective, the Mission officials enlightened the community on engaging in community projects that were of economic value. They urged families to ignore traditional circumcision on the time saving basis. According to Soita (O.I, 2015), it only required a candidate to be accompanied by his parent or guardian to the medical centres where circumcision was done. In less than ten minutes, the boy was circumcised thus saving the family two useful weeks that could be utilized elsewhere.

Among the Babukusu, circumcision offered the best avenue through which the youth acquired full rights of owning land and other valuable property in the community (Makila, 1982: 136). Property ownership began soon after the boy started his invitation visits to his close relatives. Generous relatives gave him money, chicken, goats and sometimes cows. When he visited his maiden uncles, he was sometimes given live animals to take home (Makokha, 1993: 74-75).

Boys who portrayed courage and bravery when being circumcised also attracted plenty of gifts and presents from his parents and other jubilant people. To clearly indicate that the boy was now ready to own property, a basket containing cereal crops like maize, millet and sorghum was always placed beside him few minutes after being circumcised. Traditionally, this signified the economic value of circumcision in the community.

Therefore, any attempt of transforming the traditional surgery in the community will definitely derail a very rightful traditional economic empowerment course among the Babukusu. Soon after completing the passing out stage, the new man had the right of demanding a share of his land from his parents as part of his inheritance. He quickly built his house and begun to accumulate his own wealth.

More demand for land and its acquisition by non-natives in the region who did not subscribe to the Bukusu circumcision culture also devalued the sacredness of the mudding places. Traditionally, land was communally owned (Spear, 1981: 75 and Wafula, 2000: 66) but the rising cost of the living standards led to the capitalistic mode of production where 
resources and means of production were owned and controlled by few individuals as envisaged by Karl Marx (Engels and Marx, 1952: 279-345). Subsequently, farming was intensified in most arable land including the sacred swamps. Some of the sacred swamps sold to non-Bukusu were fenced off thus interfering with the practice of the khulonga. Nevertheless, such attempts attracted opposition from the local community.

As a way of cleansing such land, IcFEM evangelistic team initiated prayer sessions that were supposed to take place in these sacred swamps. The Mission officials argued that such land were being wasted by the "barbaric" cultural rites of khulonga which was associated with witchcraft and demons (Namungu, O.I, 2015). Praying for such mudding places were meant to drive out demons and witchcraft in it which had been accumulated by the Bukusu "uncivilized" and "ungodly" culture (Nabie, O.I, 2015). The Mission evangelical team believed that by doing so, the unutilized land would be free for cultivation and eventually add value to the economic status of the people.

By 2012, IcFEM had opened its liaison centres in the entire Bungoma County and its circumcision ideologies were profoundly rooted in many parts of the county. The Mission's medical team had successfully attracted Bukusu sympathizers to its surgery and it had substantially taken over moral guidance and counseling offered to the neophytes after hospital circumcision. Traditionally, such counselling sessions were very useful in inculcating important economic knowledge to boys (Magesa, 1998: 99-100).

Before IcFEM, hospital circumcised novices were sometimes allowed to participate in the khubita sessions in traditional waysthrough which they were equipped with significant economic knowledge. Such knowledge included hunting skills, raiding knowledge, farming and also livestock rearing (Wafula, 2000: 90). All these important economic values in the traditional setup of the Bukusu circumcision did not feature anywhere in the Mission's syllabus used for such moral guiding sessions (Banda, O.I, 2014). This therefore implied that candidates who underwent medical surgery in the Mission hospital had inadequate basic traditional economic knowledge. Nevertheless, they were empowered to acquire Western education which was aimed at enabling them to acquire white-collar jobs to better their future lives.

The coming of IcFEM's medical team to provide hospital circumcision in Kimilili constituency to a large extent drove away a number of families from these traditional economic aspects. Medically circumcised novices were denied avenues of sourcing wealth during circumcision. Again, most of them were circumcised when they were still young with very little knowledge on property ownership (Murutu, O.I, 2014). This is however disputed by Biboko (O.I, 2015) who claims that the economic role of Bukusu circumcision was far much below compared to the economic benefits of medical circumcision. That is why his Mission urged the Babukusu to shun the traditional practice of circumcision.
In most cases, the Mission's finance department pledged to support the educational costs of the needy students. The mission also created an education loan scheme that allowed the needy students from the region got money to meet their school fees and refund the money later. To completely transform the uneconomical Bukusu circumcision, (Sankey, O.I, 2015) IcFEM injected KShs 6 million in the medical surgery campaigns with an aim of saving the local community up to Sh1.2 billion that was being spent in the traditional surgery.

Mr. Nabie (O.I, 2015) observed that circumcision was not an illness but a luxury in which the community invested its wealth without considering the beneficial outcome in it. He maintained that the originator of circumcision was God and it was wrong for the local community to make it expensive and dangerous. Therefore, IcFEM aspired to minimize the cost of the traditional circumcision in order to channel the said resources elsewhere to improve the quality of life to individuals and the society in general.

\section{Circumcision and Bukusu politics}

According to Magstadt (2009: 4), politics is the art of the possible, the study of who gets what, when and how, and as the authoritative allocation of values of a group of people. Magstadt maintains that politics is about the way human beings govern one another and it affects the day to day life of humanity. This therefore implies that politics is everywhere all the time and it is majorly determined by very significant underlying factors and cultures of a given group of people. In other words, issues are more or less political to an extent that the use of such politics affects life and happiness of the people. Indeed, cultures of a given community determine its political outlook and this was the case of the pre-colonial Bukusu setup in which circumcision culture dictated the nature of the political engagements in this community.

Before the reformation of the Bukusu circumcision at Mwiala by Mango, the ritual was not compulsory for all male members of the society (Makila, 1978: 170-173). However, future political leaders in the community were supposed to be circumcised. Therefore, circumcision among the Babukusu was a very significant political culture that determined the traditional political setup of the Bukusu community. On a similar discussion in Western countries, Peters (1995: 36) argues that societal and political cultures influence the conduct of public administration. Peters also maintains that political cultures in part, influences the relationship between the political and the bureaucratic elites and between population and bureaucracy. Similarly, circumcision culture among the Babukusu influenced the political engagements in its pre-colonial setup. Therefore, the current Bukusu political system and cultures had inadequate normative commitment to public morality and administration. This is probably due to what Peters refers to as Western model of bureaucracy which is alien in the Bukusu politics and which is also immoral. 
Like any other African ethnic community, the family was the most basic political unit among the Babukusu. It comprised the father who was the head of the family, the mother and children. Being the head of the house, the father had the sole authority over his family with the assistance of the mother (Fedders and Salvadori, 1979: 100-101). However, the mother was relegated to the third role in family leadership upon the circumcision of the eldest son of that family (Naulikha, O.I, 2014).

Wasike (2013: 62-63) posits that "because of the patriarchal nature of the society, the Bukusu man is always the head of the family and the centre of authority in which his word is law. His authority arises from the ownership of land and cattle which gives him economic power over women and children." Therefore, politics in Bukusu community had its genesis in families with fathers having the political mantles of such families.

Above the family, there was a clan which formed and occupied a larger territorial unit traditionally called lukoba (Wafula, 2003: 41). Now, the establishment of a family in this community was based on the successful completion of the circumcision ritual. During the passing out stage, youths were commissioned to establish their families and they joined the junior class of elders who held considerable political responsibilities at that level (Makila, 1982: 38).

Bravery, courage and tolerance formed a key element of the Bukusu circumcision. Showing no signs of fear was a significant measure of courage and bravery (Wafula, 2000: 88). It was a sign of future warriors who were expected to defend the community against external attack. In circumcision, the final test of courage and bravery lasted only up to a maximum of ten seconds and it was the moment when the actual cut was made on the organ of the boy. Those who underwent the traditional surgery testified how painful it was (Makhanu, O.I, 2015).

That was the case with Bukusu circumcision. As a sign of bravery and courage, a candidate withstood this pain. The blinking of an eye and any slight and unnecessary movement by the boy automatically made him to be referred as a coward (Magesa, 1997: 96). Such candidates were denied leading military roles and they were only permitted to handle very minor military duties. However, those who exhibited exemplary courage earned themselves front military ranks whenever going for raids or wars. They were given commanding duties and it was believed that the manner in which they led their troops brought victory on their side. They tactfully handled their opponents with utmost courage and they persevered the war just as they overcame the pain of the cut.

While in the seclusion house after circumcision, significant military and political lessons were offered to boys (Kakai, 1993: 146). In the anticipation of the establishment of a family soon after circumcision, the boy was taught leadership skills that were paramount in establishing a prudent home for raising children with desirable morals and values. Such skills included general discipline of the children, commanding authority and respect from the wife and children, taking responsibility of the family upon demise of the father among other admirable leadership traits (Wafula, 2000: 88).

Those who were to become political leaders were instructed to be good leaders particularly in the dispensation of justice. They were also encouraged to regularly attend elders' meetings where they observed how certain decisions were arrived at. Youths were also taught the importance of defending their families from external aggressions and internal feuds. The acquisition of such family leadership skills while in seclusion formed the basis upon which the entire politics of the Babukusu was supported (Makila 1982: 36).

Subjecting candidates to mockery, beatings and insults was meant to instill the virtue of humility. This is a desirable leadership quality that many democratic $21^{\text {st }}$ Century leaders have tried to exhibit (Tabani, O.I, 2014). Among the Babukusu, leaders who went against this value were dethroned instantly. This explains why prominent Bukusu politicians like the former Ministers; Musikari Kombo, Mukhisa Kituyi and Elijah Mwangale who were said to be proud politicians failed to be re-elected in subsequent general elections after their initial defeat (Banda, O.I, 2014).

However, leaders who possessed this quality were always supported by the locals and it was easy for them to climb to the summit of their political aspirations. That is why charismatic Bukusu political leaders like Masinde Muliro and the former vice president of Kenya, Michael Wamalwa Kijana received full political support by the entire Bukusu nation. It is argued that these great Bukusu politicians learned the value of humility during their circumcision rituals in 1942 and 1962 respectively.

In the secluded places of residence, boys were taught the industrial art of making weapons such machetes, arrows, bows, spears and shields. These trainings were conducted by tutors with professional knowledge and expertise in arms production. Such tutors were trained blacksmiths and they offered lessons on weapon making to selected circumcised boys whose clans had the talent of iron technology(Makila, 1978:90). Indeed, this argument is also echoed by Were (1967: 177) who observes that "with the aid of the Batikane people, the Babukusu soon began to manufacture their own arrows and thereby increased their small stock." In addition the Batikane trained the Babukusu the art of bow-and-arrow warfare until they became adept of it.Note that Bukusu clans were classified according to specific talents and gifts associated with certain spirits responsible for such talents (Wafula, 2000: 69). Each clan identified itself with a symbols that communicated their talent. For instance, clans with iron technology carried home a cylindrical metallic bar called enyuli from the mudding place to announce their talent.

The climax of military knowledge acquired while in secluded places was demonstrated during the passing out ceremony. 
Wrestling contests and mock fights were often conducted on such days (Magesa, 1997: 99-100) where neophytes demonstrated their fighting prowess as potential future warriors and defenders of their community. The novice who brought down all his opponents was declared the winner and he automatically became the leader of that group at a given locality. The contestants relied on their skills and tactics to win the tournament. They also used the weapons to demonstrate their fighting skills and those who failed to shield themselves from the opponent's club or spear surrendered the tournament (Kakai, 1993: 146).

This formed the basis of the military wing of Bukusu society. At a larger territorial unit of the community, winners of the wrestling contests at the village levels combined to form a formidable class of warriors that were not easily permeable by external aggression. This must have been the case during the Kibajenje, Lumboka and Chetambe wars between 1894 and 1895 involving the British and Babukusu (Aseka, 1989: 158160).

Since 1884 however the intended political significance of the Bukusu circumcision has been declining. The colonial intrusion in Bukusu territory dismantled the traditional political setup of this community, terming Bukusu circumcision as a "barbaric and uncivilized" culture with no civilized political value. That is why the colonial governments upon defeating the Babukusu at Chetambe and Lumboka hills outlawed their staying in forts and forests where military training was offered to circumcised boys (KNA, DC/NN/3/1: III.7: 1912-1936). These are the trainings that Hobley and Spire blamed for the stubborn nature of the Kitosh(Bukusu) community.

In 1909 for instance, the carrying of lethal weapons such as the spears, the shields and the buffalo hides was banned by the then Nyanza Provincial Commissioner, John Ainsworth. Further orders prohibiting the carrying of weapons in public were put in place in 1913 and they were contained in a "Book of Instructions" which were circulated to all chiefs (KNA, PC/NZA/3/31/3: 1913).

This scenario is also captured by Kakai (1993: 147-149) who argues that there was the decrease in using shields and spears by newly initiated men in 1920's on their days of passing out. The wearing of the skin clothes gradually decreased in 1930's after the emergence of Western mode of clothing. Nonetheless, political knowledge continued to be instilled to circumcised boys during circumcision periods although with low vigour and energy. Bukusu circumcision culture was further condemned by Christianity which was the dominant religion in the Bukusu region.

Although the independent government did not directly create a circumcision political disorder in the Bukusu community, its support forWestern education unmasked Bukusu circumcision as a Stone Age culture that was outdated with no cultural significance. Since the inception of hospital circumcision, those who have undergone the cut in hospital have been despised in general and have not been respected by the local people. Nevertheless, most of them have ventured in other productive engagements which have brought political glory to them (Nyongesa, O.I, 2014).

Since independence, the Bukusu community in Bungoma County has largely been dominated by politicians who were circumcised traditionally. According to Tabani (O.I, 2014), his political survival as a counsellor of Maeni ward by December 2007 was largely supported by his involvement in traditional circumcision. For him to achieve this he was forced to subject all his sons to traditional circumcision yet most of them were urban dwellers with very little knowledge about the Bukusu circumcision.

By December 2012, Kimilili constituency had been represented in parliament by Masinde Muliro, Elijah Mwangale Wasike, Dr. Mukhisa Kituyi and Dr. Eseli Simiyu who are all said to have been circumcised traditionally. This argument is however disputed by most Bukusu elders who assert that Dr. Mukhisa Kituyi and Dr. Eseli Simiyu went through hospital circumcision. According to Naulikha (O.I, 2014), Mukhisa's parents were very strong Christian members of the Friends church and it is unlikely that they allowed their son to be circumcised traditionally.

In fact, Makhanu (O.I, 2015) asserts that it is only one son of Jamin Kituyi Okhwamakari (Dr. Mukhisa's father) who was circumcised traditionally. This was Edward Kimungui Kituyi who was circumcised in July 1968 (bamaina age-set), contrary to the Babukusu's usual month of August. Furthermore, he did not go through all the significant phases of circumcision. Makhanu posits that Edward was woken up early in the morning, washed with cold water and he was circumcised. This was witnessed by a few people as opposed to the Bukusu cut which is always done in public.

Regarding Dr. Mukhisa, he was circumcised in 1972 (bachuma age-set) together with his biological brother Natembeya Kituyi which in essence contravened the Bukusu circumcision culture thatoutlawedthe circumcision of brothers in the same year (Naulikha, O.I, 2014). Makhanu (O.I, 2015) posits that the two were circumcised by Samson Silikhe, a medical surgeon who was based at Naitiri Market near Mukhisa's native home of Mbakalo. Thereafter, the remaining two brothers of Dr. Mukhisa (Dickson Ngutuku and Joshua Kituyi) were circumcised medically in subsequent years.

After completing his Advanced level studies in 1977 at Bokoli Secondary School, Mukhisa was admitted at the University of Nairobi to pursue a bachelor's degree in political science. He was however expelled in 1979 following his involvement in students' demonstrations who were demanding the release of political detainees including Masinde Muliro (Makhanu, O.I, 2015). With the aid of his cousin Michael Wamalwa Kijana, desperate Mukhisa was admitted at Makerere University in Uganda where he completed his political science degree. Thereafter, he got a scholarship to study a Master of Arts degree at Dar es Salaam University in Tanzania after which he 
proceeded on another Ph.D. scholarship in anthropology in a Norwegian university.

With this rich educational background, it was very easy for Dr. Mukhisa Kituyi to successfully clinch the parliamentary seat of Kimilili constituency during the 1992 general elections (Nabisiolo, O.I, 2014). Banda (O.I, 2014) argues that the then M.P of Kimilili constituency Elijah Wasike Mwangale had lost his popularity to the electorate and there was a political outcry from the local people to dethrone him. That made the then Bukusu leadership under Masinde Muliro and Michael Wamalwa Kijana to pick the educated Mukhisa as a parliamentary candidate because he possessed the charisma that Kimililians wanted (Naulikha, O.I, 2014). His educational achievements overshadowed his hospital circumcision and this explains why the electorate elected him at the expense of other contestants including the incumbent Elijah Wasike Mwangale who was circumcised traditionally.

When Dr. Mukhisa lost his political popularity to the electorate in 2007, he was succeeded by Dr. Eseli, who was a retired army officer. Like Dr. Mukhisa, Eseli was also well educated. He studied medicine at the university of Nairobi before he was recruited into the army where he rose to the rank of a major (Makhanu, O.I, 2015).He was also a lecturer at the same University andhis political victory in Kimilili constitueny had nothing to do with his circumcision. In fact many Bukusu elders claimed that Dr. Eseli was not a Bukusu and that his father Fredrick Simiyu came from the Banyala clan which is one of the seventeen sub-ethnic groups that form part of the Baluhya cluster of the inter-lacustrine region (Were, 1967: 36-38).

He served in the colonial government as a magistrate in the Local Native Council which was later changed to the African District Council. This position enabled Fredrick Simiyu to acquire land in Trans-Nzoia scheme which was largely dominated by the Babukusu. At the same time, Mr. Simiyu was also a strong Roman Catholic who did not entertain traditional cultures such as the Bukusu circumcision (Makhanu, O.I, 2015). If this claim is true then Eseli was not circumcised according to the Bukusu traditions. However, the argument that Fredrick Simiyu was not a Bukusu was disputed by Dr. Eseli himself in 2007 during his campaigns. His closest rival, Dr. Mukhisa Kituyi had capitalized on this to win the election.

Although Dr. Mukhisa lost the Kimilili parliamentary seat in 2007, Biboko (O.I, 2015) believe Kimilili people made a wise decision by not re-electing him. This gave him a golden chance to be appointed the Secretary General of the UN conference on Trade and Development. This position according to Biboko is far much better than the Kenyan politics and brave Mukhisa is likely to bounce back in Kenyan politics with much vigor and strength when his term ends at the UN.

From the foregoing discussion, it is perhaps correct to argue that circumcision in Bukusu community had very little significant political role by 2012. Politics was left in the hands of the learned and the wealthy people and those circumcised at khulupao and home had same the political fortunes at elections. In fact the khulupao candidates stood better chances of dominating in politics because most of them had excelled academically and they had also accumulated enough wealth which propelled them to easily sail through their political ambitions (Namungu, O.I, 2015).

The final criticism to the political role of circumcision in Bukusu community came in with the establishment of IcFEM in Kimilili constituency. Having fully understood the Bukusu circumcision and having critically assessed the significance of this practice to the community, the Mission came to a conclusion that circumcision itself was good and recommendable but the elaborate nature of its practice was irrelevant (Namungu, O.I, 2015). The Mission's medical team thus endeavoured to provide an alternative method of circumcision with little financial cost but with the biggestimpact on diminishing the Bukusu circumcision role in politics.

By championing for the adoption of the Mission's method of surgery, very significant political aspects of circumcision to future political kingpins were eroded. As noted before, humility was a political virtue instilled in boys during circumcision period. However, the model of circumcision offered by IcFEM's medical team had inadequate practical lessons where boys were taught how to be humble. According to the Mission officials, beatings, mockery and insults to the candidate were inhuman and they were against human rights (Chapter four of the constitution of Kenya 2010). It was a form of torture to the innocent boys hence the Mission's evangelical team took a philanthropic role of protecting young boys from such unnecessary torture.

Pain endured when being circumcised was another political aspect that was omitted from the circumcision method of IcFEM's medical team. Medical circumcision offered by the Mission's medical team and other health units usually injected candidates with anesthesia which reduced pain when being cut (Mutunda, 2009: 33). Therefore, such candidates lacked courage and bravery that was envisaged in traditional method of circumcision. They missed important sessions of inculcating political values of humility, courage and bravery as dictated by the Bukusu circumcision culture (Chikati, O.I, 2014). The eventualities of such boys in their future leadership position were swayed by new trends that did not recognize cultural norms of Bukusu politics. Be it as it may, very simple leadership position of heading their newly created familieswas sometimes an uphill task.

IcFEM model of circumcision also denied the youth important political lessons that were only provided while in seclusion places. Such boys were not taught important family concepts that were revealed to boys during this period. Such boys had inadequate basic family leadership skills which then became a setback in their future political endeavours of the community 
(Wambani, O.I, 2014). Two or three families with poor leadership skills translated into weak leadership in the council of elders at a larger territorial organization. This explains why traditional political organization of the Babukusu declined.

IcFEM officials should equally be blamed in this detrimental observation. It was offering medical circumcision that omitted seclusion sessions where such basic political lessons were taught to boys. In any case, IcFEM encouraged circumcision of young boys who were not ready to establish their families soon after healing from the circumcision wound (Wasike, O.I, 2014).

It should also be noted that important military lessons entailed in iron technology that were offered to boys when they were in secluded areas were also omitted by IcFEM's mode of circumcision. Such military technology involved making arrows, bows, spears, shields and other tools that also supported farming (Makila, 1982: 36). Although IcFEM in general played little role in transforming the spread of this military knowledge, it nevertheless takes blame because it generally opposed the traditional practice of Bukusu circumcision which in general had significant political role in the community.

In support of outlawing Bukusu circumcision, the Mission officials fully encouraged Western models of education through which youths acquired military knowledge that made traditional Bukusu arms production obsolete. Logically, this would sound very correct with the Babukusu having already been fallen by the Western made arms in their own backyard at Chatambe, Kabachenje and Lumboka forts slightly over a century ago (Masika, O.I, 2014). By 2012, almost all circumcised youths at that time had no knowledge on the traditional arms production.

The involvement of IcFEM's evangelical team in the postinitiation rituals four months after circumcision drove the last nail in the coffin of Bukusu traditional politics. The team took over the responsibility that was traditionally intended to open up new political ideas to the future community warriors and leaders. The passing out ceremonies conducted by evangelism department were totally different from that conducted by the Babukusu traditionally. Makila (1982: 44) asserts that under the Bukusu circumcision boys were taught virtues of tolerance and generosityto those who anticipated to be future leaders in the community. This was however not included in the Mission's mode of conducting the passing out stage. Lessons offered during these sessions were based on the Biblical concepts without practical political and military lessons.

Traditionally, a boy was given a spear and a shield to signify his readiness to defend the community from external aggression (Wafula, 2000: 89). In contrast however IcFEM officials offered pens and books to boys and these were seen as important weapons for fighting poverty and ignorance which were among the major challenges Kenya faced at independence. In general therefore, Bukusu crude weapons that were used for war in the pre-colonial period lost their value upon the production of more sophisticated tools with the arrival of foreigners in Kenya. Wrestling contests which were done on the day of the passing out (Makila, 1982: 136) did not feature anywhere in IcFEM's passing out stage. Even though colonialism led to the abandonment of wrestling contests, there still existed mock fights using boiled bananas and this continued to inculcate political roles to boys upon circumcision.

On this discussion however Biboko (O.I, 2015) bitterly laments that Bukusu circumcision should be blamed for the raising numbers of security guards and watchmen in cities of which most coming from the Babukusu. In his opinion, courage, bravery and pain endured during traditional circumcision has greatly contributed to this pathetic observation. Young men who pass through this ritual find it easy and convenient to look for such poor jobs rather than enhancing their studies to secure well-paying jobs.

This argument is also echoed by Nabie (O.I, 2015) who posits that the Bukusu people should re-think the political role of their circumcision because the ritual has lost its political significance and they ought to substitute it with relevant and appropriate cultures inclined towards the changing and the transforming trends in place. To them, education and wealth are significant political tools which the Babukusu should engrave in their culture should they want to be successful in politics. In any case, other ethnic communities have dominated Kenyan politics yet they do not base their political survival and achievements in their circumcision rituals. That is why Nabie (2008: 2) refers to Bukusu circumcision as a retrogressive culture with negative socio-economic and political impact.

\section{Demeaning the symbolic significance of traditional circumcision}

In the foregoing discussion, Bukusu circumcision has been depicted as a rite full of culture symbolism with relevant value and significance to the initiate and the society at large. And true to this fact, Wanyama (2005: 67) argues that "Bukusu circumcision is characterized by the taboos and the beliefs that are depicted in the actions of participants through various rituals." This implies that the ritual has symbolic actions which were done to mean something else or perhaps, pass a particular message to the initiate's future life and the entire society at large.

The ceremony entailed a myriad of symbolism hence it was not just a mere cut of the foreskin of the initiate's penis but rather sought for the divine wisdom and blessings from the spirits and ancestors. In the fuller interrogation of this cultural rite, various symbols, taboos and beliefs will suffice and if well examined, they depict other societal values and norms which may not be related to circumcision.

From a broader perspective, Bukusu circumcision generates numerous debates surrounding the concept of masculinity and the glorification of men in the society. This then leads to the 
general "conception" or "misconception" of men domineering in many spheres which can be understood alongside the construction and the perpetuation of the institutions and structures that naturally place men at the helm (Wasike 2013: 61), and circumcision stands out boldly as one of these institutions.

Silverman (1995:45) argues that male circumcision in Africa is associated with symbolic themes such as the enhancement of masculine virility, fecundity, arboreal fertility, complementary opposition between men and women, preparation for marriage, adult sexuality and the hardening of boys for warfare. "The young men are invited to exalt their paternity, their virility with its privileges and they are imbued with the ideas of their domination over women."

Among the Babukusu, the ritual is not just a rite of passage but rather a cultural benchmark which underlies the society and all its aspects including marriage. Egesah and Bailey (2006: 6) note that no man should marry among the Babukusu until he has been circumcised and it is considered an embarrassment, if not a taboo, to wed before being circumcised. In a conclusive remark thus, the ritual is the highest signifier of male identity thus making it the embodiment of sexual virility and the determinant of power relations.

According to Marx Weber (cited in Wasike 2013), the absence of women in such an institution would indicate Bukusu circumcision as essentially masculine and martial in nature since prominent stages of the rite were exclusively a preserve of men. More importantly, it reflected the masculine orientation of Bukusu life since lesser and insignificant roles such as brewing beer were accorded to women while important ritual specialists and leaders were predominantly men. This in essence gives a clear reflection on how the ritual placed men above women. Mothers were expected to come under the command of their sons upon going through the ritual. Boys on the other hand were instructed not to frequent their mother's kitchens and as such, mothers accorded their initiated sons much more respect than before (Naulikha, O.I, 2014).

But this symbolism in the practice of Bukusu circumcision lost its meaning upon the arrival of Christianity, feminist movements and other women empowerment programmes in Bukusuland and other alternative forms of circumcision that did not glorify men for having gone through the ritual. From the Biblical stories of creation, man and woman were all created in the image and likeness of God and Christianity generated the principle of equality regardless of the gender orientation of the people (Nabie, O.I, 2015).

The government of Kenya was also convinced with this notion and women were empowered to do what men can do. They capitalized on this strength to exonerate themselves from cultures and traditions that undermined and relegated them to the position of house wives and the role of bearing children (Namwenya, O.I, 2014). It was at this juncture that women coined the famous phrases "what a man can do, a woman can do better" and "behind every successful man, there is always a woman." Such assertions were constructed by women and other feminists while attempting to demystify the dominant nature and positions of men in the society.

The entry of IcFEM in the provision of hospital circumcision further belittled and demeaned the essence of masculinity and the male dominance which was developed and propagated through the traditional surgery. From the onset of the khulupao circumcision in Bukusuland by 1919 (KNA, MISS/54/212: 1919), it was unanimously agreed that women were given the privilege of conducting circumcision surgeries to boys in hospitals. This in essence went against the Bukusu's demand that forbade women from conducting the surgery to boys, a claim that is eloquently echoed by Wanyama (2005): "in the Bukusu community, women cannot qualify to circumcise." As a matter of fact, IcFEM and other medical facilities allowed women doctors and nurses to be involved in conducting the surgery to boys (Egesa and Bailey, 2006: 9). This in essence completely devalued the significance of circumcision as a symbolic epitome and as a tool for the glorification of hegemonic masculinity and male dominance in the society.

Perhaps, the significant aspect of the Bukusu circumcision that explicitly demonstrate how men used the traditional surgery to intimidate women and glorify themselves was the naked movement from the mudding place to the circumcision ground. Boys voluntarily and gladly exposed their genitals to everybody including women (Wamalwa, O.I, 2014). This was a symbolic similarity to the Freudian tenet in the Oedipus complex explanation where a boy of 3-6 years gratify his physical curiosity towards his mother by "undressing himself and fondling his penis" as if he knows that the mother while at his age developed the "penis envy stigma," another Sigmund Freud's assertion that places women below men and justify men's claim of hegemonic masculinity.

However, it is imperative to know that this public display of the initiate in total nudity evoked the concept of masculine braggadocio so that all people including girls and women could bear witness to his imminent transition from uncircumcised childhood characteristic of femininity to circumcised masculinity which shall never be disputed. With the advent of IcFEM and other health institutions that insisted on modern surgery as a form of circumcision (Egesa and Bailey, 2006: 11), chances of boys exposing their organs to women became minimal.

Even if women are circumcisers in hospitals, the boy would only expose his penis to one but not many as it was the case of Bukusu circumcision. Thus, men's main agent of selfglorification in masculinity came to a dead end when the khulupao circumcision was systematically planted in the Bukusu society. In a way therefore, circumcision appeared to have created an illusion of power that was continuously 
fantasized by many men who desired dominance (Segal 1999: 208).

The concept of the namwima (shrine) in Bukusu circumcision had a wider symbolic socio-cultural and religious significance that was held with high esteem by the society at large. Makila (1982: 178) argues that the shrine symbolized a permanent feature of a family's involvement in religious warship and sacrificial observance. A part from the circumcision ceremonies, the holy shrines were also erected in homesteads during other social-religious events that warranted the symbolic presence of God.

Circumcision was thus one of the events that depicted the significance of the namwima in the society. Its construction entailed various trees such as kumusola (Markhamiaplatycalyx), kumulaha (Cambretumbindlranum), kumusunu and kumukomosi (Vangueriaapiculata). These trees symbolized success, bearing of many children and wealth among other meanings (KNA, DC/EN/3/2/4: 1929-1935).

Because hospital circumcision conducted by IcFEM has no room for the construction of the namwima, the significance of this structure among the Babukusu is becoming irrelevant. Henceforth, Bukusu community will be seen as a society without any traditional heritage that was represented in the symbolism of the namwima (Wambani, O.I, 2014). Significant trees such as kumusola, kuтиsunu, kumukhendu, kumulaha and kumukomosi have already lost their intended symbolic meanings that were envisaged by the drafters of the imbalu (traditional surgery) ritual among the Babukusu. More fundamentally, the interpretation of the namwima and other symbolic rituals in Bukusu circumcisionby Western informed mindset to mean witchcraft and idolatry has demeaned the significance bestowed in the holy shrine and in the entire circumcision ritual as well.

Circumcision songs were very significant in the entire process of the circumcision ritual among the Babukusu (Simiyu, 2011: 144). Some of the songs had symbolic meanings that were coded intentionally to hide the intended messages and they only required intelligent and senior people in the community to interpret such songs to the youths through what Wasambo (2014: 84) calls informal methods of learning. This fact is also echoed by Wanyama (2005: 1) who observes that music was used as a carriage that embodied relevant messages among Africans. The structure of most African songs entailed various forms of short solo response phrases and more often the language used was proverbial.

Note that each circumcision stage had peculiar songs that were sang to convey the intended message meant for that phase. During khuminya, songs were sang for various reasons. Most of the songs were meant to encourage boys to show exemplary courage the following day as they faced the surgery. They also passed important advice to the entire community. Some songs encouraged prescribed behaviour while candidly condemned proscribed behaviour. Some songs were vulgar and ridiculous while some served as vent off in which people said the abominable including sexuality and socially stigmatized behaviour (Simiyu, 2011: 144).

Other songs depicted prime historical moments among the Babukusu. A song like amba Mutalia for instance ishistorical in nature. This song was composed during the Second World War when the British were fighting against the Germans and the Italians. The Bukusu's way of life had been so disrupted by the war that they wanted to chase away the Italians and maintain their culture (Wasambo 2014: 93). In Wasike's (2013: 73) words, "what this naming captures in metaphorical terms is the aftermath of the Second World War that had just ended. In that war the Italians as part of the Axis powers had been conquered by the Allied forces, hence the ridiculing and demeaning phrase 'catch the Italian' which is the literal English translation of amba Mutalia." During that period, circumcision ceremony had to be postponed.

But there are two other significant songs in the entire process of Bukusu circumcision which were sang in all initiation ceremonies to pass relevant historical and traditional intended vices and norms of the community across generations (Wanyama and Egesa, 2015: 11). The famous sioyaye chant is perhaps a symbolic song that was sang with high esteem and it reminded the Babukusu how they earned their ritual through Mango, their forefather (Wasambo 2014: 13-15). Through this song, the community identified people who were likely to become circumcisers if they indicated that they were possessed with the kimisambwa kie bukhebi (circumcision spirits).

Khwera omurwa was another important song that was sang upon the completion of the five to ten seconds circumcision surgery. Barwa (plural for omurwa) refers to a clan within the Kalenjin community that occupied the slopes of Mount Elgon. They were the perennial enemies of the Babukusu and the khwera omurwa song signified the triumphant moment in the Babukusu history over the Barwa (Wanyama and Egesah, 2015: 13). It reflected that moment when the Babukusu exonerated themselves from the oppressive hands of the Barwa.

That being the case the above symbolic significance of circumcision songs will be of no value should Nabie's men and other anti-Bukusu circumcision succeed in transforming this traditional practice of the Babukusu completely (Khalaba, O.I, 2014). Circumcision will be like any other casual and secular rite and it will be meaningless and inappropriate for its preservation through oral traditions.

But the custodians of the Bukusu cultural heritage and morality are yet to give up on enhancing and promoting the traditional rite in the modern secularized Bukusu community. That is why there existed conflicting relations between those circumcised in hospital and their fellow initiates that faced the traditional surgery. This also explains why IcFEM's agenda of conducting hospital circumcision was strongly opposed by the custodians of the Bukusu culture whose main aim was to preserve the symbolic significance of their ritual. 


\section{CONCLUSION}

We conclude this discussion by stating that customary institutions do not simply come out of a cultural void and continue repetitively through time as traditional ethnographies always claim. They are generated out of historical conditions ultimately as people re-shape their cultures to changes in their environment, mode of production and their social circumstances. What may have been appropriate way of life in one set of conditions becomes inappropriate as the same conditions are exposed to dynamics. People are always coming across new situations with ideas and modes of behaviour based on earlier ones. There is thus a continuous process in history by which people adapt to changes and transform their cultural situations.

Circumcision in Bukusu community is historical, purposeful, procedural and cultural. It is deeply embedded in the community and any attempt of transforming it is likely to register less meaningful positive response due to the resilience ultimately exhibited by the Babukusu. As a cultural value of the community, it played a key role of ushering youth into adulthood which was followed by marriage. However, the ritual has been a centre of focus since the inception colonialism. Several attempts have been made aimed at transforming its operation but the community has stood its ground, protecting and jealously guarding it.

It is also worth to note that Bukusu circumcision had three broader roles in the spheres of humanity. It had social, economic and political roles. It was a mandatory obligation and its complicated and tedious mode of practice madethe community to be perceive as being "barbaric" and "uncivilized culture." The onset of the modernity in Africa therefore, coincided with continuing crisis of modernity in the continent. Colonial imperialism imposed modernity and cultures of Western European enlightenment with belief in scientific rationalism, universal culture, truth, order and religion.

This relegated African cultures such as Bukusu circumcision to lower leagues of cultural obligations. During the colonial period, Africans were trained to perceive things from a Western European standpoint often universalized to embrace all humanity. Consequently, Western ideas informed all the intellectual discourses about Africa which eventually criminalized values and cultures of Africa.

The independent government of Kenya also continued to perpetuate the ideologies of western mindset regarding local African cultures. Significant Kenyan cultures like female circumcision were criminalized by the independent government and the widespread of Christianity in the country enhanced the erosion of more cultures such polygyny, traditional male circumcision, traditional liquors, ways of worship among others.

By 1988, Christianity had reached Bungoma District of Kenya and there were continued attempts by this religion to further erode the existing local African cultures. Kimilili Constituency too attracted Christianity which desired to change the lives of the Babukusu to reflect the doctrines enshrined in this religion.

At the same time, IcFEM begun to engage the people of Kimilili in the socio-economic perspectives of the region. Indeed, the mission instituted remarkable operations that resulted to the improved living standards of the local people. Regardless of the positive contribution of IcFEM in the socioeconomic wellbeing of the people, the Babukusu remained adamant with their traditional circumcision and they have continued to practice the traditional surgery amidst the opposition from the mission. Their desire to preserve this unique circumcision culture perhaps explains this observation.

It is also coherent to note that this traditional ritual still has a cultural significance in a postmodern Kenyan society that has been interacting with cultural ideas of the western countries. The perception of being a peculiar community in Kenya is informed by their continued practice of this ritual and there is a likelihood that this traditional surgery of the Babukusu will continue to survive in future.

\section{REFERENCES}

\section{a) Published and unpublished sources}

[1]. Aseka, E. M. (1989), Political Economy of Buluhya Land,19001964, Ph.D. Dissertation, Nairobi; KenyattaUniversity.

[2]. Bloom, L.\& Ottong, J. G. (1987), Changing Africa, an Introduction to Sociology. London;Macmillan Publishers.

[3]. Clayden G \& Lissauer, (2011), Illustrated Text Book of Pediatrics, Fourth Edition. New York: ISBN.

[4]. De Wolf, J. (1977), Differentiation and Integration in Western Kenya: A study of Religious Innovation and Social Change among the Bukusu. The Hague: Mouton.

[5]. Doornobs, M. (1975),Regalia Galore, the Decline and Eclipse of Ankole Kingship. Nairobi: EALB.

[6]. Egesah, O. \& Bailey, R. C. (2006). Assessment of Clinical and Traditional Male Circumcision Services in Bungoma District, Kenya: Complication Rates and Operational Needs, Special report.

[7]. Engels, F. \& Marx, K. (1952), Manifesto of the Communist Party, London: William Benton Publishers.

[8]. Fanon, F. (1963), The Wretched of the Earth,Great Britain: Mcgibbon \& Kee.

[9]. Fedders, A. \& Salvadori, C. (1979), Peoples and Cultures of Kenya. Nairobi; Trans-Africa.

[10]. Havilland, W. A. (1975), Cultural Anthropology, Florida; Harcourt Brace Company.

[11]. Hoogvelt, A. M. M, (1976).The Sociology of Developing Societies. London: Macmillan Educational Publishers.

[12]. Hulme, M. \& Turner, M. (1990), Sociology and Development, THEORIES, POLICIES ANDPRACTICES, Portsmouth; Biddles Ltd, Guildford.

[13]. Kakai, W. P. (1992), Social Concept in the Initiation Rituals of the Abatachoni, a HistoricalStudy, M.A Thesis, Kenyatta University Press.

[14]. Kenyatta, J. (1978), Facing Mount Kenya, London; Warburg publishers.

[15]. Khamalwa, W. (2004), Identify, Power and Culture: Imbalu Initiation Ritual among the Bamasaba of Uganda.Bayreuth; Thielmann \& Eckhard Breitinger.

[16]. Magesa, L. (1998), African Religion, Limuru; Kolbe Press.

[17]. Makila, F. E. (1978), An Outline History of the Babukusuof Western in Kenya. Nairobi; K.L.B. 
[18]. (1982),The Significance of Chetambe Fort in Department of Culture official Monograph.

Bukusu,

[19]. Makokha, K. T. (1993), Relationship between Morality andReligion: A case of Babukusu of Western Kenya,M.A Thesis, Kenyatta University.

[20]. Moi, D. (1983), Kenya, 1963-1983, Kenya Official Handbook. Nairobi: Government of the Republic of Kenya.

[21]. Moi, D. (1986),Kenya African Nationalism, Nyayo Philosophy and Principles,Nairobi: MacmillanPublishers.

[22]. Mugambi, J. \& Karima, N. (1976), The African Religious Heritage, a Text Book Based on Syllabus 228 of Kenya Certificate Education,Nairobi; OxfordUniversity Press.

[23]. Mugenda, O. M. and Mugenda, A. G. (1999), Research Methods: Quantitative and Qualitative Approaches, Nairobi: Acts Press.

[24]. Muller, M, et al (2009). Male Circumcision for Preventionof Heterosexual Acquisition of HIV in Men, NewYork: Cochrane Database of System Reviews.

[25]. Muraya, M. W. (2009), Colonial Transformation of Female Circumcision and its Impact on Women's Role andGender Relations among the Gikuyu of KiambumFrom 1895 to 1963. Nairobi; Kenyatta University,M.A Thesis.

[26]. Mutunda, S. N. (2009). Through a Female Lens: Aspects ofMasculinity in Francophone African Women'sWriting, Ph.D. Thesis, University of Arizona.

[27]. Nabie, S. (2008), A Strategic Action for Mitigating the Spread of HIV/AIDS Through Traditional Circumcision Practice in Bungoma North, East, South and West Districts and Mt. Elgon, TransNzoia, Teso and Lugari Districts in July/August 2008, Unpublished paper.

[28]. The Nation Newspaper of $11^{\text {th }}$ August 2004.

[29]. Obel, A. (1995), Curbing the HIV/AIDS Menace Effectively, Nairobi: Circuit City Limited.

[30]. Parrinder, G. (1976), African Traditional Religion, NewYork: Green-wood press publishers.

[31]. Peristiany, J. G. (1939), The Social Institution of the Kipsigis, London: Routledge and Kegan.

[32]. Peters, G. B. (1995), The Politics of Bureaucracy, an Introduction to Comparative and Public Administration, New York: Longman.

[33]. Segal, L. (1999), Why Feminism? Oxford, Blackwell.

[34]. Shell, D.\& Hernlund, Y. (2000), "Female Circumcision" inAfrica, Colorado; Lynne Rienner Publisher.

[35]. Silverman, E. K.(2004), Anthropology and Circumcision, in a journal of Annual Review of AnthropologyVol. 33 p 419-45.

[36]. Simiyu, R. N. (2011), Socio - Cultural Significance of Circumcision Songs within a Changing Babukusu Community of Bumula Division, M.A Thesis, Nairobi: Kenyatta University Publishers.

[37]. Spear, T. (1981), Kenya's Past, An Introduction to Historical Methods in Africa, United Kingdom: Longman Group Limited.

[38]. Tignor, R. L. (1976), The Colonial Transformation of Kenya, New Jersey. Princeton University.

[39]. Wafula, P.W. (2000),Politics and Nationalism in Colonial Kenya: The Case of the Babukusu of Bungoma District, C. 1894-1963, M.A Thesis, Kenyatta University.

[40]. Wafula, P.W.(2003), The History of CommunityRelations across the Kenya-Uganda Boarder; The Case of the Babukusu and Bagisu, C. 1884-1997, Ph.D. Thesis, Kenyatta University.

[41]. Wagner, G. (1949), The Bantu of North Kavirondo, vol 1.New York: Oxford University Press.

[42]. Wanyama, M. (2005), Form and Context of African Music; A Case Study of Bukusu Circumcision Music,Ph.D. Thesis,Pretoria; Pretoria University.

[43]. Wanyama, M. and Egesah, O. (2015),Ethnography and Ethnomusic of Babukusu Traditional Male Circumcision; Messaging, Symbolism and Rationale, Moi University: DOI:10.13189/sa.2015.030102

[44]. Wasambo, W. (2014),A Traditional Ritual Ceremony as Edurama: A Case Study of Imbalu Ritual among the Bukusu of Western Kenya, Ph.D. Thesis. Nairobi; Kenyatta University.
[45]. Wasike, C. (2013), Textualizing Masculinity: Discourses of Power and Gender Relations in Manguliechi's Bukusu After burial Oratory Performance (khuswala kumuse),Unpublished Thesis,Johannesburg; University of Witwatersrand.

[46]. Wasilwa, I. M. M. (2014), Traditional Cultural ApproachAwareness on HIV/AIDS, Circumcision trainingmanual, Bungoma: Kenya Charter.

[47]. (2006),Lukembe Sikhebo Association of Kenya Circumcision Objectives (Lubito), Bungoma: Kenya Charter.

[48]. Were, G. S. (1967), A History of the Abaluhya of Western Kenya. Nairobi; E.A.L.B.

[49]. Were, E. A. (2012), Community Involvement in theIntegration of Science and Technology in Traditional Male Circumcision Practices: A Case of Bungoma County Kenya,Methodist University (Nairobi Campus).

[50]. WHO, (2009), Traditional Male Circumcision among theyoung People, Public Health Perspective in the context of HIV Prevention. Geneva: WHO printing services.

b) Archival sources

[1]. KNA, DC/NN 3/1/: 1902-1916, Political record book, North Kavirondo part 1: General Description of theDistrict.

[2]. KNA, MISS/54/212: 1919, Report of the work at Kitosh Station, By J. W. Ford.

[3]. KNA, DC/NN 3/5/: 1912-1936, Political Records: Hut and Poll Tax.

[4]. KNA, PC/NZA 3/31/8/1: 1913, Ethnology of Tribes of North Kavirondo District by Dunda

[5]. KNA, DC/EN/3/2/4: 1929-1935, Political Records, Ethnology

[6]. KNA, DC/NN 10/1/5: 1946-1949, Dini Ya Musambwa.

\section{c) Oral evidence}

[1] Alex Tabalia Wekesa, 63 years old, interviewed on $29^{\text {th }}$ August 2015 at Lumuli village, Kamusinde location, Kimilili constituency. He is a retired forester.

[2] Ben Nyongesa, 73 years old, interviewed on $23^{\text {rd }}$ August 2014 at Sitabicha Village, Kimilili rural sub-location, Kimilili constituency. Veterinary practitioner by profession.

[3] Benedict Kunusia Wanjala, 49 years old, interviewed on $3^{\text {rd }}$ December 2014 at Malaha Village, Maeni Location. He is the Chief of Maeni location.

[4] Edward Chikati, 39 years old, interviewed on $6^{\text {th }}$ December 2014 at Sitabicha village, Kimilili rural sub-location. $\mathrm{He}$ is the area assistant Chief.

[5] Gabriel Naulikha Kunusia, 93 years, interviewed on $9^{\text {th }}$ August 2014 at Matoma village, Kamasielo Sub-location, Kimilili constituency. He is a retired Primary School teacher.

[6] Gabriel Wamalwa Murutu, 64 years old, interviewed on $13^{\text {th }}$ December 2014 at Buko village, Sikhendu sub-location, Maeni Location, Kimilili constituency. He is a retired Primary School teacher.

[7] Godwin Masika Makokha, 49 years old, interviewed on $17^{\text {th }}$ November 2014 at Kaptola village, Kibingei location, Kimilili constituency. He is a teacher at Bituyu FYM Primary School and also holds a B.Ed. (arts) degree from Kenyatta University.

[8] Hosea Wasike, 83 years old, interviewed on $20^{\text {th }}$ September 2014 at Kamutiong'i village, Kamusinga sub-location, Kibingei Location, Kimilili constituency. A medical doctor by profession.

[9] Henry Mwambu Murutu, 61 years old, interviewed on $13^{\text {th }}$ December 2014 at Buko village, Sikhendu sub-location, Maeni Location, Kimilili constituency.

[10] Jackson Nabiswa Walekhwa, 91 years old, interviewed on $16^{\text {th }}$ August 2014 at Kamusinde village, Nasusi Sub-location, Kimilili constituency. He is a retired primary school teacher.

[11] James Khalaba, 72 years old, interviewed on $3^{\text {rd }}$ August 2014 at Bituyu village, Kimilili Division, Kimilili constituency. He is a traditional circumciser and also chairs the association of Lukembe circumcisers. 
[12] Joseph Nyongesa Cheloti, 65 years old, interviewed on $18^{\text {th }}$ November 2014 at Matoma village, Kamasielo Sub-location, Kimilili constituency. He is a member of the Bukusu council of elders' board based in Bungoma town.

[13] Lesley Sankey, 65 years old, interviewed on $26^{\text {th }}$ August 2015 at IcFEM's offices, Kibingei Location, Kimilili constituency. She is a native of the United Kingdom but currently works as the personal assistant to the director of IcFEM.

[14] Macdon Namungu Juma, 49 years old, interviewed on $26^{\text {th }}$ August 2015 at IcFEM's offices, Kibingei Location, Kimilili constituency. $\mathrm{He}$ is the deputy director in charge of operations and the Mission chaplain.

[15] Margaret Soita, 56 years old, interviewed on $28^{\text {th }}$ August 2015 at Dreamland Mission Hospital, Kibingei Location, Kimilili constituency. She is the administrator of the Hospital.

[16] Moses Banda Wafula, 77 years old, interviewed on $2^{\text {nd }}$ August 2014 at Kibisi Village, Sikhendu Sub-location, Kimilili constituency. A former member of Kenya National Farmers Union (KNFU) and currently a peasant farmer.

[17] Musikiti Kusimba, 56 years old, interviewed on $23^{\text {rd }}$ August 2014 at Chetambe estate, Kimilili Town, Kimilili constituency. He formerly worked with the National Intelligence Service of Kenya.

[18] Patrick Biboko, 49 years old, interviewed on $26^{\text {th }}$ August 2015 at IcFEM's offices, Kibingei Location, Kimilili constituency. He is the assistant director, Mercy and Justice Pillar.

[19] Patrick Nabisiolo Kituyi, 77 years old, interviewed on $16^{\text {th }}$ November 2014 at Matoma Village, Kamasielo Sub-location, Kimilili constituency. A student of renowned Bukusu orator, Manguliechi.

[20] Priscilla Lusike Namwenya, 63 years old, interviewed on $2^{\text {nd }}$ August 2014 at Kibisi Village, Sikhendu Sub-location, Kimilili constituency. Practices farming.
[21] Richard Makhanu Wafula, 55 years old, interviewed on $12^{\text {th }}$ July 2015 at Kahawa Wendani estate, Kasarani constituency, Nairobi. He holds a PhD (Kiswahili) from Kenyatta University and he currently chairs the Kiswahili department at the same University.

[22] Roseline Nelima Nandabi, 45 years old, interviewed on $17^{\text {th }}$ August 2014 at Kaptola village, Kibingei location, Kimilili constituency. She is a teacher at Khwiroro AC primary school and currently pursuing a B.Ed. (arts) degree at Kenyatta University.

[23] Ruth Eshimuli Nabie, 51 years old, interviewed on $28^{\text {th }}$ August 2015 at Dreamland Mission Hospital, Kibingei Location, Kimilili constituency. She is the wife to Mr. Nabie. She is also the Chief Executive Officer of the Hospital.

[24] Solomon Nabie, 53 years old, interviewed on $27^{\text {th }}$ August 2015 at IcFEM's offices, Kibingei Location, Kimilili constituency. He is the director of IcFEM.

[25] Willington Wambani Wafula, 69 years old, interviewed on $19^{\text {th }}$ August 2014 at Matoma village, Nasusi Sub-location, Kimilili constituency. He is a traditional circumciser.

[26] Winy Wanyama, 53 years old, interviewed on $3^{\text {rd }}$ December 2014 at Nasusi trading center, Nasusi Location, she is the area Chief of Kamusinde location.

[27] Wycliffe Tabani Wepukhulu, 58 years old, interviewed on $6^{\text {th }}$ January 2015 at Sikhendu village, Sikhendu sub-location, Maeni Location, Kimilili constituency. $\mathrm{He}$ is the former mayor of Kimilili municipality and also served as the councilor of Maeni ward up to December 2007.

[28] Zipporah Naulikha Kunusia, 66 years old, interviewed on $9^{\text {th }}$ August 2014 at Matoma village, Nasusi Sub-location, Kimilili constituency. 
International Journal of Research and Innovation in Social Science (IJRISS) |Volume V, Issue XII, December 2021||ISSN 2454-6186 